\title{
Production of Pre Ripened Provolone Cheese and Quality Characterization Using Blends of Whole Milk
}

\author{
Yosef Alemneh $^{1 *} \quad$ Shimelis Admassu ${ }^{2} \quad$ Kidist Fikre ${ }^{3}$ \\ 1.Department of Food Science and Post-Harvest Technology, Oda Bultum University, P.O. Box. 226, Chiro, \\ Ethiopia \\ 2.Department of Department of Chemical Engineering, Addis Ababa Institute of Technology, Addis Ababa \\ University, Ethiopia \\ 3.Department of Food Science and Post-Harvest Technology, Hawassa University
}

\begin{abstract}
Cheese is a product made from the curd obtained from milk by coagulating the casein with the help of rennet in the presence of lactic acid produced by added starter culture. The study was aimed to evaluate the yield and quality of pre ripened provolone cheese prepared from different blends of cow, doe, ewe and camel whole milk. The sources of milk were from Hawassa town, Langano and Kofele areas of Oromiya region. Pre ripened provolone cheeses were made from blends contained ratio between $60-80 \%, 10-30 \%, 10-30 \%$ and $0-20 \%$ for cow, doe, ewe and camel milk, respectively using standard procedure. The whole milk and its pre ripened provolone cheeses were subjected to physicochemical analyses. The physicochemical analyses, selected minerals, bioactive compounds, microbial quality and consumer acceptability of the pre ripened provolone cheese were analyzed. The blending proportion of different milk had significant $(\mathrm{P}<0.05)$ effect on the physiochemical property, mineral, bioactive and sensory quality of pre ripened provolone cheese. The physiochemical property of whole milk for manufacture of pre ripened provolone cheeses were in the range between 10.56 to $15.08 \%$ for total solids, 3.45 to $5.20 \%$ for fat and 3 to $4.19 \%$ for crude protein. The chemical composition of pre ripened provolone cheese prepared from different blended milk ranged from $47.32-67.05 \%$ for total solids, $24.26-36.81 \%$ for fat, $17.78-26.30 \%$ for crude protein, $1.09-3.49 \%$ for total ash, and $0.75-2.98 \%$ for lactose; ascorbic acid $(0.49$ to $3.08 \mathrm{mg} / \mathrm{kg})$ and total polyphenols (1.00 to 17.50 ( $\mathrm{mg} \mathrm{GAE} / \mathrm{g}$ ). The fat, protein and total solids recovery of pre ripened provolone cheeses ranged from $64.87 \%$ to $95.39 \%, 54.58 \%$ to $84.67 \%$ and $41.35 \%$ to $59.92 \%$ respectively. The yield of pre ripened provolone cheese ranged from $9.22 \%$ to $13.47 \%$. Total bacteria count was found to be the predominant micro flora of pre ripened provolone cheeses and reached $5.24 \mathrm{cfu} / \mathrm{g}$ in the control cheese. The entire consumer acceptability of the pre ripened provolone cheese was in acceptable range. In conclusion, the pre ripened provolone cheese prepared from T12 (60\% cow, 10\% doe and 30\% ewe) milk gave better cheese yield and had auspicious results in nutritional qualities comparable with that of control cheese and other cheese samples.
\end{abstract}

Keywords: Blends of whole milk, cheese yield, pre-ripened provolone cheese, quality characterization

DOI: $10.7176 /$ ALST/82-01

Publication date:October $31^{\text {st }} 2020$

\section{INTRODUCTION}

Cheese is one of the most widely consumed fermented dairy products with a growing consumer demand. Cheese is a fresh or matured product obtained by the drainage of liquid after the coagulation of milk, cream, skimmed or partly skimmed milk, butter milk or a combination them (Sadia et al., 2016). Provolone is a typical semi-hard drawn-curd cheese and it became popular around the end of the $19^{\text {th }}$ century when it began to be produced in the southern regions of Italy (Ministero Agricoltura e Foreste, 1992).

Cheese is a nutrient-dense food, the precise nutritional composition and it is a popular food, a good source of nutrients and is generally considered as part of a healthy diet. The type of milk gives the cheese different nutritional and organoleptic properties.

In Ethiopia, milk is produced and marketed to consumer without being pasteurized. About $98 \%$ of the annual milk produced by subsistence farmers who live in rural areas where dairy processing in the country is basically limited to smallholder level and hygienic qualities of products are generally poor (Zelalem and Faye, 2006). Milk and milk products form part of the diet for many Ethiopians. They consume dairy products either as fresh milk or in fermented or soured form. Felleke and Geda (2001) estimated that $68 \%$ of the total milk produced is used for human consumption in the form of fresh milk, butter, yogurt and cheese while the rest is given to calves and wasted in the process.

Cheese can be manufactured from different types of milk. In regions where fresh milk is scarce, cheese has been successfully made from recombined anhydrous milk fat and reconstituted skim milk powder. However, it can produce cheese from cows, ewes, does and camel's milk and their combination (O'Connor, 1993). For instance, ewe milk is considered more appropriate than cow milk for the production of good quality cheese (Sadia Rasheed, 2016).

Therefore, the aim of the present study was thus to utilize the different milk types, notably cow, doe, ewe and 
camel milk for manufacture of pre ripened provolone cheese. With this aim there is a need to study the effect of different blending of milk on the Physiochemical, bioactive component microbial characteristics and sensory quality of pre ripened provolone cheese.

\section{MATERIALS AND METHODS}

\subsection{Sample Collection and Transportation}

A total of 70 liters of fresh milk was collected for Cheese making. Four types of raw milk samples (cow, doe, ewe and camel) were used for cheese making. Camel milk and Cow milk were collected from bulbula village and Hawassa town respectivelty. Fresh doe and ewe milk were collected from Langano area and Kofele particularly from Ashoka (A village $15 \mathrm{~km}$ from Kofele). The samples were immediately placed in ice box and transported to Hawassa University Food Science laboratory. Then after the milk sample was stored for $4^{\circ} \mathrm{c}$ until the cheese was prepared..

\subsection{Experimental Design and Treatments}

The blending formulation of cow, doe, ewe and camel milk is presented (Table 1). Design expert 7.0 software was used for the blending of each milk to make Provolone cheese. The experimental design was completely randomized design (CRD) for physicochemical properties, bioactive compounds and microbial load and Randomized Complete Block Design (RCBD) for the sensory analysis. In this experiment, the different milks were first collected from the available source. The different milks were then blended for pre ripened provolone cheese manufacturing. The blended whole milk samples were analyzed and then cheese was developed.

\subsubsection{Blending}

Table 1: Blend formulations of cow, doe, ewe and camel milk for cheese preparation

\begin{tabular}{lcccc}
\hline $\begin{array}{l}\text { Run } \\
\text { order }\end{array}$ & Cow milk (\%) & Doe milk (\%) & Ewe milk (\%) & Camel milk (\%) \\
\hline 1 & 80.00 & 10.00 & 10.00 & 0.00 \\
2 & 75.00 & 10.00 & 10.00 & 5.00 \\
3 & 70.00 & 10.00 & 20.00 & 0.00 \\
4 & 70.00 & 15.00 & 10.00 & 5.00 \\
5 & 70.00 & 10.00 & 15.00 & 5.00 \\
6 & 65.00 & 10.00 & 15.00 & 10.00 \\
7 & 65.00 & 15.00 & 10.00 & 10.00 \\
8 & 65.00 & 20.00 & 10.00 & 5.00 \\
9 & 65.00 & 10.00 & 10.00 & 15.00 \\
10 & 60.00 & 10.00 & 10.00 & 20.00 \\
11 & 60.00 & 15.00 & 15.00 & 10.00 \\
12 & 60.00 & 10.00 & 30.00 & 0.00 \\
13 & 60.00 & 10.00 & 20.00 & 10.00 \\
14 & 60.00 & 30.00 & 10.00 & 0.00 \\
15 & 60.00 & 20.00 & 20.00 & 0.00 \\
16 & 60.00 & 20.00 & 10.00 & 10.00 \\
Control & 100.00 & 0.00 & 0.00 & 0.00 \\
\hline
\end{tabular}

\subsection{Manufacture of Pre ripened Provolone Cheese}

Process of pre ripened provolone cheese was conducted according to the method as described by codex, (2016) presented (Figure 1). Cow milk was the experimental control. The blended milk samples were pasteurized at $63^{\circ} \mathrm{C}$ for 30 minutes in batch pasteurizer. Then the milk was cooled to $37^{\circ} \mathrm{C}$ in order to add starter culture (S.thermophilus + L.bulgaricus) at $2 \% \mathrm{w} / \mathrm{v}$ and kept for 20 minutes. About $1.5 \mathrm{~g} / 100 \mathrm{~L}$, milk rennet was added and kept for 40 minutes. After that, the curd was cut and cooked at $42^{\circ} \mathrm{C}$ for 40 minutes. The desired $\mathrm{pH}$ of the curd was $\mathrm{pH} 5.5$ for stretch it. Then the cheese was stretched and molded in molding tube and it was put for overnight on working table. Then the cheese was removed from the mold and immersed in to brine (20\%) for 5 hours. 


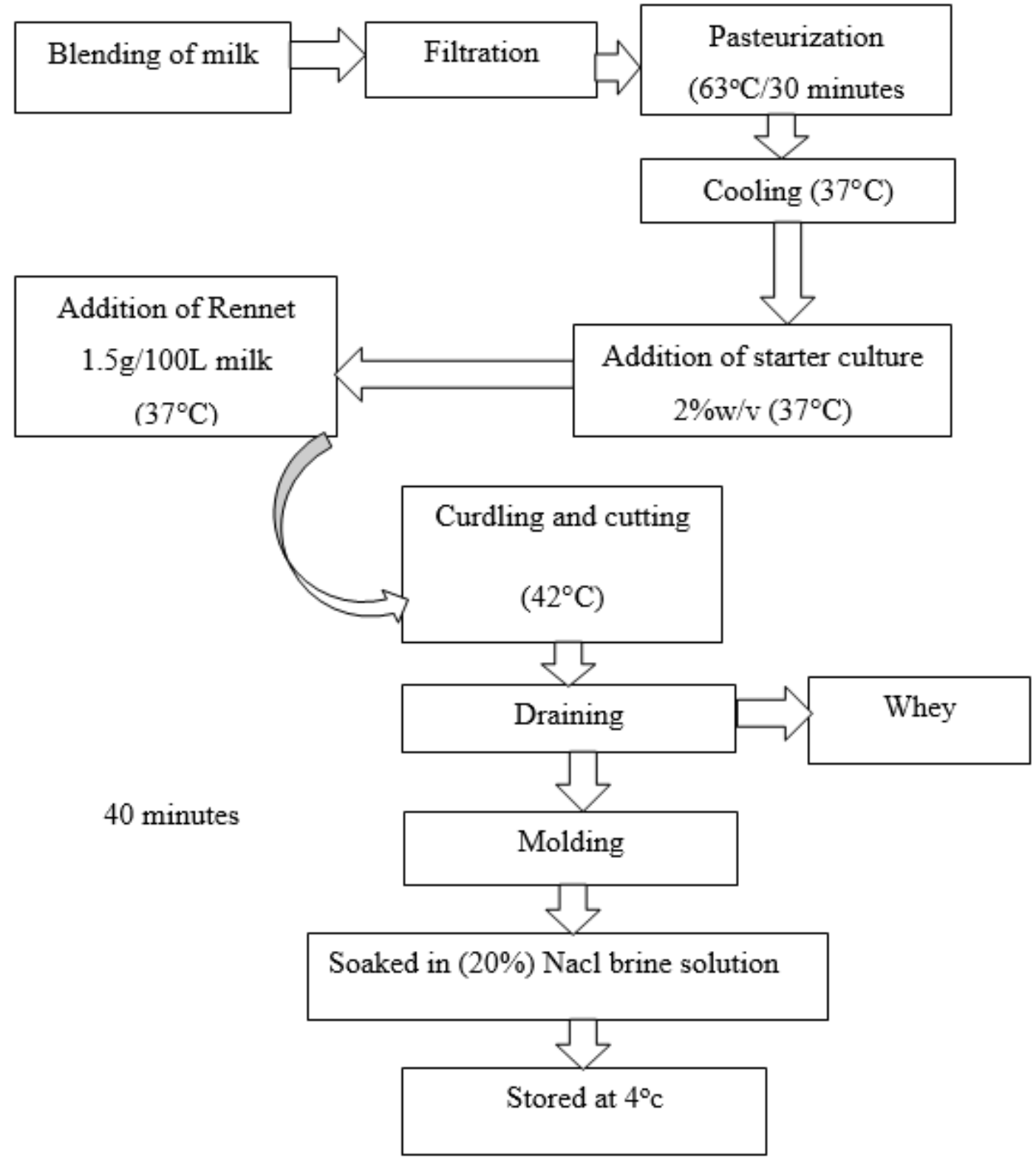

Figure 1: Flow diagram illustrating pre ripened provolone cheese preparation

\subsection{Analysis Methods}

2.4.1. Characterization of milk

The whole cow milk and different blends of milk obtained by the blend proportion were characterized in terms of $\mathrm{pH}$, acidity, total solids, lactose, protein, fat and total minerals (ash), using methodology of (Richardson, 1985) and AOAC (2006).

\subsubsection{Characterization of Pre-ripened Cheese}

Each cheese samples was determined for total solids, fat, protein, ash and lactose according to the method described by Richardson (1985). Cheese yield was calculated as a weight of cheese divided by weight of milk expressed as a percentage (Kosikowski and Mistry, 1997). Recoveries of components (protein, fat and total solid) was calculated as the component in the cheese divided by the original weight of the component in the milk expressed as percentage as suggested by Mehaia (1993).

\subsubsection{Bioactive compounds}

Total polyphenols

The total polyphenol content in the cheese samples were determined by the method of Claudia et al. (2008). $1 \mathrm{ml}$ Folin Ciocalteu reagent (diluted ten times) were added and the mixture was left for $5 \mathrm{~min}$ and then $1 \mathrm{ml}(75 \mathrm{~g} / \mathrm{L})$ of sodium carbonate was added. The absorbance of the resulting blue color was measured at $765 \mathrm{~nm}$ with a UVvisible spectrophotometer (JENWAY, 63000, UK) after incubation for $90 \mathrm{~min}$ at room temperature. 
Ascorbic acid

Ascorbic acid was determined according to the method of (Nweze et al., 2015). The equivalence point of the titration determined using a starch indicator. $20 \mathrm{~mL}$ of filtrate sample was added into a $125 \mathrm{~mL}$ Erlenmeyer flask. $25 \mathrm{~mL}$ of distilled water and $1 \mathrm{~mL}$ of starch indicator solution was added. Then the sample titrated with standardized iodine solution.

2.4.4. Microbiological quality of cheese

Microbiological analysis (Total Bacteria Count, Total coliform count and Yeast and mold) of the pre ripened provolone cheeses was conducted by the method of IDF (1985) by using spread plate technique.

2.4.5. Consumer acceptability

Sensory acceptability of the cheeses was evaluated according to the method of Iwe (2010) using 5-point hedonic scale. Twenty panelists were selected for evaluating the sample. The analysis was conducted in duplicate with 5point hedonic scale $(1=$ dislike extremely, $2=$ dislike moderately, $3=$ neither like nor dislike, $4=$ like moderately and $5=$ like extremely).

\subsection{Statistical Data Analysis}

The data was subjected to one factor of variance (ANOVA) used SAS (Statistical Analysis System, version 9; SAS Institute, 2001). All the samples were analyzed in duplicates and Duncan 's multiple-range test for mean comparison with at significance level of $5 \%$ was used.

\section{RESULTS AND DISCUSSION}

\subsection{Physiochemical Property of Whole Blended Milk and Provolone Cheese}

\subsubsection{Physiochemical property of whole blended milk}

The physicochemical properties of different blended milk in comparison with those of cow milk were presented (Table 4). The results show that $\mathrm{pH}$ value of various milk samples varied from $6.40 \pm 0.01$ to $6.61 \pm 0.01$. Maximum $\mathrm{pH}$ was found in case of cow milk (6.62), while results presented that $\mathrm{pH}$ value of $\mathrm{T} 16(60 \% \mathrm{cow}, 20 \%$ doe, $10 \%$ ewe and $10 \%$ camel) milk was significantly $(\mathrm{P}<0.0001)$ lower than cow milk sample.

The higher $\mathrm{pH}$ of raw cow milk is due to the transportation handling system and the location of milk that was collected. Raw cow milk was collected from hawassa town and other milk samples were transported from the area far from hawssa and this could result the decrement of $\mathrm{pH}$ due to long transportation time. The lower $\mathrm{pH}$ in $\mathrm{T} 16$ may be due to the production of acid resulting from bacterial growth and multiplication in the milk samples (O’Connor, 1995). Sadia et al. (2016) reported that, lower pH of milk could be because of milk composition and amount of normal flora in the milk during transportation and storage. The $\mathrm{pH}$ of milk samples used for the development of pre ripened provolone cheeses in the current study were within the normal range (Walstra, 2006). The $\mathrm{pH}$ value found in cow milk was in agreement with the findings of Kanwal et al. (2004) and Hanna (2015). The $\mathrm{pH}$ of control and blended milk in the current study was fit for coagulation and cheese production. Kheadr et al. (2003) reported that $\mathrm{pH}$ values between 5 and 7 are said to generally best for coagulation of milk.

The titratable acidity of milk blended from $(60 \%$ cow, $20 \%$ doe, $10 \%$ ewe and $10 \%$ camel) milk (T16) was significantly $(\mathrm{P}<0.0001)$ higher than the titratable acidity values of $100 \%$ cow milk (control) and other treatments except T13 and T14. The cow milk was recorded lower titratable acidity value than other milk types used for pre ripened provolone cheese preparation. The lower titratable acidity in cow milk may be due to the higher amount of $\mathrm{pH}$. Mahmood and Usman (2010) reported that low $\mathrm{pH}$ has been found to increase acidity which is due to increased lactic acid bacteria.

In this study, the titratable acidity of blended milk was increased with the decrement of cow milk. This may be due to the production of lactic acid bacteria in the doe, ew and camel milk during transportation. The titratable acidity of cow milk in the current study is similar with the finding of (Enb et al., 2009). However the titratable acidity of blended milk is higher the titratable acidity value reported by (O'Connor, 1995). This might be due to bacterial growth and multiplication during transportation before cheese preparation.

Results illustrated that total solid content of cow milk and blended milk measured between $10.56 \pm 0.10$ to $15.08 \pm 0.25 \%$. Statistical analysis showed a significant $(\mathrm{P}<0.0001)$ difference of the total solid content due to the blending proportion of milk. The total solid content of control (100\% cow) milk was (12.66) which is significantly differ from T12 and T10 which have the highest and lowest value of total solids content. The blended milk prepared from $\mathrm{T} 12$ (60\% cow, 10\% doe and 30\% ewe) milk had significantly $(\mathrm{P}<0.0001)$ higher $(15.08 \%)$ total solids content than the control and other samples. While the lowest total solids in T10 $(60 \%$ cow, $10 \%$ doe, $10 \%$ ewe and $20 \%$ camel $)$ milk which was significantly $(\mathrm{P}<0.0001)$ lower $(10.56 \%)$ than the other treatments. The higher total solids of T12 is because high proportion of ewe milk causes increment of total solids of blended milk and the high composition the milk compared to the other treatments. Derar and El Zubeir (2014) reported that total solids content was increasing as the amount of ewe milk incorporated in the blended milk was increasing. The TS $(14.50 \pm 0.32)$ content of blended camel milk found by Amenu and Deeth (2007) was higher compared to the finding of the current study. The total solids content of cow milk in the current study which is slightly comparable with the result of Gemechu et al. (2015) who found total solid in milk from Shashemene town (12.87 \pm 0.11 ). This 
variation might be due to different species and environmental condition. Different values of total solid content of raw milk samples have been reported by different scholars. The variation could be due to difference in breed, feeding and managing practices which have important effects on milk composition and quality (O' Connor, 1995; Pandya and Ghodke, 2007).

Results presented that fat content of $(60 \%$ cow, $10 \%$ doe and $30 \%$ ewe) milk (T12) was significantly $(\mathrm{P}<0.0001)$ higher than other milk samples while minimum fat content was observed in T10 $(60 \%$ cow, $10 \%$ doe, $10 \%$ ewe and $20 \%$ camel) milk. In the current study the fat content of cow (control) milk (4.60) was not significantly differ from other treatments except T3, T7, T9, T8 T10, and T12. This result was comparable with the finding of Hanna, (2015). On the other hand, Sadia et al., (2016) observed that the lower fat content of cow milk compared to the current study. In the present study, fat content of different blended milk samples was lower than the finding of Pandya and Ghodke (2007) who observed that fat content of different types of milk varied from $3.7 \%$ to $7.90 \%$. This difference might be due the type of breed in which the milk produced.

The control sample had protein content of 3.46, which is lower than the result founded by (Amenu and Deeth, 2007). This difference might be due to different in breed and type of feeding. During this research work, maximum amount of protein was found in T12 (60\% cow, $10 \%$ doe and 30\% ewe) milk as compared to the rest of milk samples. However, minimum protein content was observed in T10 (60\% cow, $10 \%$ doe, $10 \%$ ewe and $20 \%$ camel) milk that resembled to the findings of Amenu and Deeth (2007) which was $2.9 \pm 0.13$. Protein content of different blends of milk found in this study was lower than reported by Zedan (2014). This might be due to difference species and environmental condition.

Table 2: Physicochemical properties of whole blended milk

\begin{tabular}{|c|c|c|c|c|c|}
\hline Treatments & $\mathrm{pH}$ & TA $(\%)$ & TS \% & Fat $\%$ & Protein \% \\
\hline Control & $6.62 \pm 0.01^{\mathrm{a}}$ & $0.17 \pm 0.01^{\mathrm{f}}$ & $12.66 \pm 0.21 \mathrm{de}$ & $4.60 \pm 0.29^{\mathrm{cd}}$ & $3.46 \pm 0.03^{\mathrm{def}}$ \\
\hline $\mathrm{T}_{1}$ & $6.58 \pm 0.04^{\mathrm{ab}}$ & $0.19 \pm 0.01^{\mathrm{ef}}$ & $12.91 \pm 0.10^{\mathrm{cd}}$ & $4.80 \pm 0.14^{\mathrm{bc}}$ & $3.57 \pm 0.12^{\mathrm{c}-\mathrm{f}}$ \\
\hline $\mathrm{T}_{2}$ & $6.54 \pm 0.01^{\mathrm{bcd}}$ & $0.19 \pm 0.00^{\mathrm{ef}}$ & $12.44 \pm 0.08^{\mathrm{def}}$ & $4.55 \pm 0.07^{\text {cde }}$ & $3.39 \pm 0.12^{\mathrm{ef}}$ \\
\hline $\mathrm{T}_{3}$ & $6.57 \pm 0.03^{\mathrm{abc}}$ & $0.19 \pm 0.00^{\mathrm{ef}}$ & $14.03 \pm 0.12^{\mathrm{b}}$ & $5.00 \pm 0.14^{\mathrm{ab}}$ & $3.94 \pm 0.09^{\mathrm{ab}}$ \\
\hline $\mathrm{T}_{4}$ & $6.50 \pm 0.01^{\text {cde }}$ & $0.18 \pm 0.00^{\text {ef }}$ & $12.23 \pm 0.28^{\mathrm{efg}}$ & $4.55 \pm 0.07^{\text {cde }}$ & $3.47 \pm 0.06^{\mathrm{def}}$ \\
\hline $\mathrm{T}_{5}$ & $6.54 \pm 0.04^{\mathrm{bcd}}$ & $0.17 \pm 0.00^{\mathrm{f}}$ & $12.90 \pm 0.14^{\mathrm{cd}}$ & $4.85 \pm 0.07^{\mathrm{bc}}$ & $3.84 \pm 0.08^{\mathrm{bc}}$ \\
\hline $\mathrm{T}_{6}$ & $6.50 \pm 0.01^{\mathrm{cde}}$ & $0.17 \pm 0.00^{\mathrm{f}}$ & $12.04 \pm 0.23^{\mathrm{fg}}$ & $4.55 \pm 0.07^{\mathrm{cde}}$ & $3.48 \pm 0.25^{\mathrm{def}}$ \\
\hline $\mathrm{T}_{7}$ & $6.53 \pm 0.00^{\mathrm{bcd}}$ & $0.17 \pm 0.01^{\mathrm{f}}$ & $11.89 \pm 0.13^{\mathrm{g}}$ & $4.10 \pm 0.14^{\mathrm{f}}$ & $3.65 \pm 0.25^{\mathrm{cde}}$ \\
\hline $\mathrm{T}_{8}$ & $6.54 \pm 0.02^{\mathrm{bcd}}$ & $0.20 \pm 0.00^{\mathrm{de}}$ & $12.85 \pm 0.16^{\mathrm{cd}}$ & $4.25 \pm 0.21^{\mathrm{ef}}$ & $3.28 \pm 0.03^{\mathrm{fg}}$ \\
\hline $\mathrm{T}_{9}$ & $6.51 \pm 0.01^{\mathrm{bcd}}$ & $0.20 \pm 0.02^{\mathrm{de}}$ & $11.04 \pm 0.08^{\mathrm{h}}$ & $3.70 \pm 0.14^{\mathrm{g}}$ & $3.28 \pm 0.07^{\mathrm{fg}}$ \\
\hline $\mathrm{T}_{10}$ & $6.49 \pm 0.07^{\mathrm{def}}$ & $0.20 \pm 0.01^{\mathrm{def}}$ & $10.56 \pm 0.10^{\mathrm{i}}$ & $3.45 \pm 0.07^{\mathrm{g}}$ & $3.00 \pm 0.03^{\mathrm{h}}$ \\
\hline $\mathrm{T}_{11}$ & $6.44 \pm 0.01^{\mathrm{efg}}$ & $0.21 \pm 0.03^{\mathrm{cde}}$ & $12.10 \pm 0.42^{\mathrm{fg}}$ & $4.60 \pm 0.14^{\mathrm{cd}}$ & $3.05 \pm 0.12^{\mathrm{gh}}$ \\
\hline $\mathrm{T}_{12}$ & $6.47 \pm 0.04^{\mathrm{d}-\mathrm{g}}$ & $0.24 \pm 0.01^{\mathrm{bcd}}$ & $15.08 \pm 0.25^{\mathrm{a}}$ & $5.20 \pm 0.14^{\mathrm{a}}$ & $4.19 \pm 0.09^{\mathrm{a}}$ \\
\hline $\mathrm{T}_{13}$ & $6.48 \pm 0.03^{\mathrm{def}}$ & $0.25 \pm 0.03^{\mathrm{abc}}$ & $12.82 \pm 0.40^{\mathrm{cd}}$ & $4.60 \pm 0.14^{\mathrm{cd}}$ & $3.63 \pm 0.21^{\text {cde }}$ \\
\hline $\mathrm{T}_{14}$ & $6.42 \pm 0.03^{\mathrm{fg}}$ & $0.26 \pm 0.01^{\mathrm{ab}}$ & $13.16 \pm 0.12^{\mathrm{c}}$ & $4.45 \pm 0.07^{\mathrm{de}}$ & $3.53 \pm 0.00^{\mathrm{def}}$ \\
\hline $\mathrm{T}_{15}$ & $6.49 \pm 0.03^{\mathrm{def}}$ & $0.23 \pm 0.01^{\mathrm{bcd}}$ & $13.88 \pm 0.11^{\mathrm{b}}$ & $4.85 \pm 0.07^{\mathrm{bc}}$ & $3.72 \pm 0.09^{\mathrm{bcd}}$ \\
\hline $\mathrm{T}_{16}$ & $6.40 \pm 0.01^{\mathrm{g}}$ & $0.29 \pm 0.03^{\mathrm{a}}$ & $12.14 \pm 0.06^{\mathrm{fg}}$ & $4.30 \pm 0.14^{\mathrm{def}}$ & $3.39 \pm 0.05^{\mathrm{ef}}$ \\
\hline
\end{tabular}

${ }^{\mathrm{a}-\mathrm{h}}$ All values are presented in mean \pm standard deviation; Values within the same column with different superscript letters are significantly $(\mathrm{p}<0.05)$ different from each other.

T1-T16: Treatment 1-Treatment 16

\subsubsection{Physiochemical property of pre ripened provolone cheese}

Table 5 shows the $\mathrm{pH}$ and titratable acidity values during storage period for the different pre ripened provolone cheese types. Results indicated that the average $\mathrm{pH}$ value of pre ripened provolone cheese prepared from cow (control) milk and different blends of milk samples varied from $5.14 \pm 0.03$ to $5.46 \pm 0.06$ ( $1^{\text {st }}$ day) storage (Table 5). The $\mathrm{pH}$ value of pre ripened provolone cheese prepared from $(60 \% \mathrm{cow}, 10 \%$ doe, $10 \%$ ewe and $20 \%$ camel) milk (T10) observed in the present study was higher than the other treatments throughout the storage day $\left(1^{\text {st }}\right.$ up to $3^{\text {rd }}$ day). This might be due to high proportion of camel milk from other treatments. This observation is in agreement with $\mathrm{pH}$ values reported by (Haider et al., 2004). The lowest $\mathrm{pH}$ value (5.14 \pm 0.03$)$ was observed in cheese samples made from pure cow milk (control) in the present study.

The $\mathrm{pH}$ values observed between the $1^{\text {st }}$ and $3^{\text {rd }}$ days of storage cow milk cheese in the present study are in total agreement with the previous results of Asfawosen (2017), who reported a value of $5.2 \pm 0.21$ in cow's milk cheese. The $\mathrm{pH}$ value of control cheese made from pure cow milk is higher than the finding of Ashenafi (2006) who reported $\mathrm{pH}$ value ranging from 3.7 to 4.6. The $\mathrm{pH}$ values of cheese made from blended milk (T1-T16) are in agreement with the $\mathrm{pH}$ value range of (4.3-4.7) reported by (O'Mahony, 1988). During storage, the decrease in $\mathrm{pH}$ was most rapid in $100 \%$ cow milk and slowest in that of T10 milk. This difference in the rate of $\mathrm{pH}$ decrease resulted from higher amount of camel milk in T10 from other treatments. The presence lactoferrin; lactoperoxidase and immunoglobulin prevent the growth of lactic acid bacteria and the $\mathrm{pH}$ slightly decreased during storage compared with those in other milk (El-Agamy, 2000). It can be also seen that there was a decrease in the $\mathrm{pH}$ of all 
cheeses starting from the first to third day storage. Similar trend in the $\mathrm{pH}$ of Cheddar cheese made from cow milk was reported by (Walstra, 2006).

The result of titratable acidity during storage period for pre ripened provolone cheeses prepared from cow (control) milk and different blends of milk were tabulated (Table 5). In the current study, the titratable acidity of pre ripened provolone cheese manufactured from cow milk was higher than that of other cheese samples (T1-T16) throughout the storage period. This value was higher than the finding of Abdel et al. (2012), who reported a value of $0.59 \pm 0.90 \%$. This difference may be due to the environmental condition and type of coagulant used. On the other hand the titratable acidity of pre ripened provolone cheese prepared from $(60 \%$ cow, $10 \%$ doe, $10 \%$ ewe and $20 \%$ camel) milk (T10) was lower throughout the storage period compared to control and other samples. This might be the amount of lactose available in cheese. The shortage of lactose could thus reduce the activity of lactic acid bacteria and the acid production in the cheese (El-Agamy, 2006). Therefore the lower amount of acidity in cheese sample made from (60\% cow, $10 \%$ doe, $10 \%$ ewe and $20 \%$ camel) milk (T10) had high amount of camel milk than the other treatments and camel milk by nature had the property of antimicrobial activity and decrease the production of lactic acid bacteria which produce lactic acid in the cheese (El-Agamy, 2000). In the current study, the increased in acidity of all cheese samples during storage showed the activity of starters added during cheese manufacturing. Azarnia et al. (2006) reported that the primary function of starters is the conversion of lactose and other sugars in milk to lactic and other acids. The titratable acidity of the cheese samples was higher than the finding of (Ahmed and El Zubeir, 2011). This difference may be due to the environmental condition in which the cheese sample stored; the method of cheese preparation and the type of milk used.

Table 3: $\mathrm{pH}$ and titratable acidity of pre ripened provolone cheese made from different blends of milk during storage at $4^{\circ} \mathrm{C}$ for 3 days

\begin{tabular}{|c|c|c|c|c|c|c|}
\hline \multirow[t]{2}{*}{ Treatment } & \multicolumn{2}{|c|}{$1^{\text {st }}$ day } & \multicolumn{2}{|c|}{$2^{\text {nd }}$ day } & \multicolumn{2}{|c|}{$3^{\text {rd }}$ day } \\
\hline & pH & $\mathbf{T A}$ & pH & $\mathbf{T A}$ & pH & $\mathbf{T A}$ \\
\hline Control & $5.14 \pm 0.03^{\mathrm{e}}$ & $0.65 \pm 0.02^{\mathrm{a}}$ & $4.79 \pm 0.08^{\mathrm{d}}$ & $0.74 \pm 0.02^{\mathrm{a}}$ & $4.09 \pm 0.05^{\mathrm{g}}$ & $0.87 \pm 0.02^{\mathrm{a}}$ \\
\hline $\mathrm{T}_{1}$ & $5.31 \pm 0.03^{\mathrm{bcd}}$ & $0.55 \pm 0.04^{b}$ & $4.83 \pm 0.08^{\mathrm{cd}}$ & $0.67 \pm 0.05^{\mathrm{abc}}$ & $4.20 \pm 0.03^{\mathrm{efg}}$ & $0.84 \pm 0.03^{\mathrm{abc}}$ \\
\hline $\mathrm{T}_{2}$ & $5.30 \pm 0.03^{\mathrm{bcd}}$ & $0.56 \pm 0.01^{\mathrm{b}}$ & $4.94 \pm 0.04^{\mathrm{bcd}}$ & $0.70 \pm 0.03^{\mathrm{ab}}$ & $4.27 \pm 0.01^{\mathrm{ef}}$ & $0.84 \pm 0.02^{\mathrm{abc}}$ \\
\hline $\mathrm{T}_{3}$ & $5.27 \pm 0.01^{\text {bcd }}$ & $0.57 \pm 0.01^{\mathrm{ab}}$ & $4.97 \pm 0.03^{\mathrm{bcd}}$ & $0.65 \pm 0.06^{\mathrm{abc}}$ & $4.28 \pm 0.02^{\mathrm{ef}}$ & $0.79 \pm 0.02^{\mathrm{c}}$ \\
\hline $\mathrm{T}_{4}$ & $5.27 \pm 0.01^{\mathrm{bcd}}$ & $0.53 \pm 0.08^{\mathrm{bc}}$ & $4.97 \pm 0.03^{\mathrm{bcd}}$ & $0.65 \pm 0.11^{\mathrm{abc}}$ & $4.23 \pm 0.11^{\mathrm{efg}}$ & $0.85 \pm 0.02^{\mathrm{ab}}$ \\
\hline $\mathrm{T}_{5}$ & $5.31 \pm 0.01^{\mathrm{bcd}}$ & $0.53 \pm 0.08^{\mathrm{bc}}$ & $5.00 \pm 0.01^{\mathrm{a}-\mathrm{d}}$ & $0.64 \pm 0.11^{\mathrm{abc}}$ & $4.23 \pm 0.14^{\mathrm{efg}}$ & $0.81 \pm 0.03^{\mathrm{abc}}$ \\
\hline $\mathrm{T}_{6}$ & $5.34 \pm 0.01^{\mathrm{abc}}$ & $0.48 \pm 0.02^{\text {bcd }}$ & $5.08 \pm 0.21^{\mathrm{ab}}$ & $0.55 \pm 0.01^{\mathrm{cd}}$ & $4.53 \pm 0.04^{\mathrm{bc}}$ & $0.63 \pm 0.01^{\mathrm{e}}$ \\
\hline $\mathrm{T}_{7}$ & $5.26 \pm 0.02^{\mathrm{b}-\mathrm{e}}$ & $0.43 \pm 0.04^{\mathrm{d}}$ & $5.09 \pm 0.18^{\mathrm{ab}}$ & $0.55 \pm 0.05^{\mathrm{cd}}$ & $4.43 \pm 0.08^{\mathrm{cd}}$ & $0.64 \pm 0.04^{\mathrm{e}}$ \\
\hline $\mathrm{T}_{8}$ & $5.28 \pm 0.06^{\mathrm{bcd}}$ & $0.53 \pm 0.06^{\mathrm{bc}}$ & $4.97 \pm 0.03^{\mathrm{bcd}}$ & $0.66 \pm 0.09^{\mathrm{abc}}$ & $4.34 \pm 0.06 \mathrm{~d}^{\mathrm{e}}$ & $0.81 \pm 0.01^{\mathrm{abc}}$ \\
\hline $\mathrm{T}_{9}$ & $5.39 \pm 0.01^{\mathrm{ab}}$ & $0.45 \pm 0.01^{\mathrm{cd}}$ & $5.06 \pm 0.06^{\mathrm{abc}}$ & $0.48 \pm 0.03^{\mathrm{d}}$ & $4.85 \pm 0.06^{\mathrm{a}}$ & $0.60 \pm 0.01^{\mathrm{e}}$ \\
\hline $\mathrm{T}_{10}$ & $5.46 \pm 0.06^{\mathrm{a}}$ & $0.40 \pm 0.01^{\mathrm{d}}$ & $5.22 \pm 0.11^{\mathrm{a}}$ & $0.47 \pm 0.06^{\mathrm{d}}$ & $4.91 \pm 0.08^{\mathrm{a}}$ & $0.58 \pm 0.01^{\mathrm{e}}$ \\
\hline $\mathrm{T}_{11}$ & $5.33 \pm 0.14^{\mathrm{bcd}}$ & $0.44 \pm 0.01^{\mathrm{cd}}$ & $5.04 \pm 0.13^{\mathrm{abc}}$ & $0.54 \pm 0.01^{\mathrm{cd}}$ & $4.63 \pm 0.08^{b}$ & $0.63 \pm 0.05^{\mathrm{e}}$ \\
\hline $\mathrm{T}_{12}$ & $5.21 \pm 0.02^{\mathrm{de}}$ & $0.55 \pm 0.03^{\mathrm{b}}$ & $4.94 \pm 0.03^{\mathrm{bcd}}$ & $0.65 \pm 0.02^{\mathrm{abc}}$ & $4.13 \pm 0.05^{\mathrm{fg}}$ & $0.80 \pm 0.01^{\mathrm{bc}}$ \\
\hline $\mathrm{T}_{13}$ & $5.32 \pm 0.08^{\mathrm{bcd}}$ & $0.42 \pm 0.03^{\mathrm{d}}$ & $5.09 \pm 0.03^{\mathrm{ab}}$ & $0.56 \pm 0.12^{\mathrm{bcd}}$ & $4.66 \pm 0.02^{\mathrm{b}}$ & $0.69 \pm 0.03^{\mathrm{d}}$ \\
\hline $\mathrm{T}_{14}$ & $5.22 \pm 0.06^{\text {cde }}$ & $0.53 \pm 0.03^{b c}$ & $5.04 \pm 0.01^{\mathrm{abc}}$ & $0.74 \pm 0.01^{\mathrm{a}}$ & $4.65 \pm 0.02^{b}$ & $0.83 \pm 0.01^{\mathrm{abc}}$ \\
\hline $\mathrm{T}_{15}$ & $5.20 \pm 0.05^{\mathrm{de}}$ & $0.53 \pm 0.02^{\mathrm{bc}}$ & $5.04 \pm 0.01^{\mathrm{abc}}$ & $0.74 \pm 0.01^{\mathrm{a}}$ & $4.66 \pm 0.03^{b}$ & $0.86 \pm 0.03^{\mathrm{a}}$ \\
\hline $\mathrm{T}_{16}$ & $5.32 \pm 0.06^{\mathrm{bcd}}$ & $0.44 \pm 0.03^{\mathrm{cd}}$ & $5.12 \pm 0.13^{\mathrm{ab}}$ & $0.52 \pm 0.06^{\mathrm{cd}}$ & $4.61 \pm 0.02^{b}$ & $0.63 \pm 0.01^{\mathrm{e}}$ \\
\hline
\end{tabular}

${ }^{\mathrm{a}-\mathrm{g}}$ All values are means $\pm \mathrm{SD}$; Values with in the same column with different superscript are significantly $(\mathrm{P}<0.05)$ different

T1 - T16: Treatment 1 - Treatment 16

In the current study, control sample $(100 \%$ cow) milk cheese had total solid content of $57.19 \pm 0.71$. In this study, as the amount of camel milk for samples mixed with other milk type's increased, the total solid content was decreased following the naturally abundant water available in the camel milk (Abdel Rahman et al., 2009). Based on their total solid content the cheese sample coded T12 had higher total solid content and the lowest moisture content implies best quality because lower moisture content of cheese helps the cheese to have longer shelf life. According to Adegoke et al. (1992) higher moisture could favor the growth and proliferation of microorganisms and thus reduces the shelf life of cheese.

Statistical analysis showed significant $(\mathrm{P}<0.0001)$ influence of different blends of milk on protein content of pre ripened provolone cheese. The present results are in accordance to those reported by (Ogunlade, 2017). The protein content found for T10 cheese was lower than that reported by Derar and El Zubei (2014) who found 24.86 $\pm 4.1 \%$ and higher than the value reported by Ahmed and El Zubeir (2011) who found $16.12 \pm 0.71 \%$. T12 (60\% cow, $10 \%$ doe and $30 \%$ ewe) pre ripened provolone cheese had the highest protein content than the control and other samples because ewe milk had high amount of protein. Anifantakis (1996) reported that ewe milk has the ability to recover high protein in cheese making. The protein values discovered in this study were higher than those reported by earlier researchers on cheese and these values are 5.33\% (Frazier and Westhoff, 1988) and 12.86\% (Uaboi-Egbenni et al., 2010), but lower than the findings of Fashakin and Unokiwedi (1992) who reported 44.5\%. 
Results illustrated that fat content of pre ripened provolone cheese in the range of $24.26 \pm 0.81$ and $36.81 \pm 0.40 \%$. Pre ripened provolone cheese prepared from $(60 \%$ cow, $10 \%$ doe and $30 \%$ ewe milk) (T12) had significantly $(\mathrm{P}<0.0001)$ higher fat contents $(36.81 \%)$ than the other treatments, while the cheese made from T10 had the least fat content. There was an increase in fat content of cheese with the composition of sheep milk mixed in each milk samples. According to Sadia et al. (2016), the presence of high amount ewe milk during cheese preparation affects the fat content of cheese. The lower fat content observed in T10 indicates that, cheese can be stored over a longer period without developing rancid flavors (Ogunlakin et al., 2012). The current results are in accordance with the findings of Khan and Masud (2013), who observed 21.4 to $23.6 \%$ fat content. Similar result reported regarding fat content of cheese made from cow milk (Kassa, 2008). Masud (1992) further reported that differences in fat content of cheese might be due to losses of fat with whey during cheese preparation.

Table 4: Chemical composition of pre ripened provolone cheese made from different blends of whole milk

\begin{tabular}{|c|c|c|c|c|c|}
\hline \multirow[t]{2}{*}{ Treatments } & \multicolumn{5}{|c|}{ Parameters } \\
\hline & Fat $\%$ & Protein \% & Total solids \% & Ash \% & Lactose \% \\
\hline Control & $29.75 \pm 1.51^{\mathrm{e}}$ & $23.38 \pm 0.45^{\text {cde }}$ & $57.2 \pm 0.71^{\mathrm{cde}}$ & $1.09 \pm 0.10^{\mathrm{f}}$ & $2.98 \pm 0.33^{\mathrm{a}}$ \\
\hline $\mathrm{T} 1$ & $29.79 \pm 0.10^{\mathrm{e}}$ & $23.75 \pm 0.45^{\text {bcd }}$ & $58.17 \pm 0.57^{\mathrm{cd}}$ & $2.17 \pm 0.34^{\mathrm{de}}$ & $2.46 \pm 0.18^{\mathrm{abc}}$ \\
\hline $\mathrm{T} 2$ & $28.30 \pm 0.53^{\mathrm{efg}}$ & $22.60 \pm 0.14^{\mathrm{e}}$ & $55.93 \pm 0.45^{\mathrm{de}}$ & $2.53 \pm 0.11^{\mathrm{b}-\mathrm{e}}$ & $2.50 \pm 0.04^{\mathrm{abc}}$ \\
\hline $\mathrm{T} 3$ & $34.28 \pm 0.89^{\mathrm{b}}$ & $24.22 \pm 0.49^{\mathrm{bc}}$ & $62.38 \pm 1.34^{\mathrm{b}}$ & $2.76 \pm 0.23^{b c}$ & $1.12 \pm 0.66^{\mathrm{bc}}$ \\
\hline $\mathrm{T} 4$ & $27.70 \pm 0.44^{\text {fgh }}$ & $22.65 \pm 0.17^{\mathrm{e}}$ & $55.86 \pm 0.99^{\mathrm{de}}$ & $2.74 \pm 0.18^{\mathrm{bcd}}$ & $2.82 \pm 0.56^{\mathrm{ab}}$ \\
\hline T5 & $29.80 \pm 0.52^{\mathrm{e}}$ & $22.50 \pm 0.40^{\mathrm{e}}$ & $57.57 \pm 1.04^{\text {cde }}$ & $2.48 \pm 0.10^{\text {cde }}$ & $2.79 \pm 0.02^{\mathrm{ab}}$ \\
\hline T6 & $27.32 \pm 0.63^{\text {fgh }}$ & $20.51 \pm 0.62^{\mathrm{f}}$ & $52.35 \pm 1.88^{\mathrm{f}}$ & $3.08 \pm 0.04^{\mathrm{ab}}$ & $1.44 \pm 0.59^{\mathrm{abcd}}$ \\
\hline $\mathrm{T} 7$ & $26.56 \pm 0.08^{\mathrm{hi}}$ & $20.55 \pm 0.07^{\mathrm{f}}$ & $51.14 \pm 0.49^{\mathrm{f}}$ & $2.76 \pm 0.28^{\mathrm{abc}}$ & $1.33 \pm 0.27^{\mathrm{a}-\mathrm{d}}$ \\
\hline $\mathrm{T} 8$ & $27.01 \pm 0.22^{\mathrm{gh}}$ & $21.01 \pm 0.13^{\mathrm{f}}$ & $52.8 \pm 1.21^{\mathrm{f}}$ & $2.57 \pm 0.05^{\mathrm{b}-\mathrm{e}}$ & $2.21 \pm 1.51^{\mathrm{a}-\mathrm{d}}$ \\
\hline Т9 & $25.13 \pm 0.38^{\mathrm{ij}}$ & $18.72 \pm 0.49^{g}$ & $48.00 \pm 0.05^{\mathrm{g}}$ & $3.40 \pm 0.12^{\mathrm{a}}$ & $0.75 \pm 0.29^{d}$ \\
\hline $\mathrm{T} 10$ & $24.26 \pm 0.81^{\mathrm{j}}$ & $17.78 \pm 0.93^{\mathrm{h}}$ & $47.32 \pm 0.59^{\mathrm{g}}$ & $3.49 \pm 0.07^{\mathrm{a}}$ & $1.79 \pm 0.78^{\mathrm{a}-\mathrm{d}}$ \\
\hline T11 & $31.35 \pm 0.68^{d}$ & $20.73 \pm 0.26^{f}$ & $56.29 \pm 0.87^{\mathrm{de}}$ & $3.00 \pm 0.16^{\mathrm{abc}}$ & $1.21 \pm 0.08^{\mathrm{bcd}}$ \\
\hline $\mathrm{T} 12$ & $36.81 \pm 0.40^{\mathrm{a}}$ & $26.30 \pm 0.57^{\mathrm{a}}$ & $67.06 \pm 1.06^{\mathrm{a}}$ & $2.68 \pm 0.62^{\mathrm{b}-\mathrm{e}}$ & $1.27 \pm 0.28^{\mathrm{bcd}}$ \\
\hline $\mathrm{T} 13$ & $29.41 \pm 1.21^{\mathrm{e}}$ & $22.97 \pm 0.14^{\mathrm{de}}$ & $56.17 \pm 1.19^{\mathrm{de}}$ & $2.92 \pm 0.16^{\mathrm{abc}}$ & $0.87 \pm 0.04^{\mathrm{cd}}$ \\
\hline T14 & $32.20 \pm 0.31^{\mathrm{cd}}$ & $23.42 \pm 0.22^{\text {cde }}$ & $59.17 \pm 0.71^{\mathrm{c}}$ & $2.13 \pm 0.35^{\mathrm{e}}$ & $1.42 \pm 0.271^{\mathrm{abc}}$ \\
\hline $\mathrm{T} 15$ & $33.37 \pm 0.47^{b c}$ & $24.49 \pm 0.06^{\mathrm{b}}$ & $62.30 \pm 1.04^{\mathrm{b}}$ & $2.46 \pm 0.29^{\text {cde }}$ & $1.98 \pm 1.27^{\mathrm{a}-\mathrm{d}}$ \\
\hline T16 & $28.85 \pm 0.92^{\mathrm{ef}}$ & $21.46 \pm 0.50^{\mathrm{f}}$ & $54.79 \pm 0.64^{\mathrm{e}}$ & $2.94 \pm 0.06^{\mathrm{abc}}$ & $2.54 \pm 1.11^{\mathrm{abc}}$ \\
\hline
\end{tabular}

${ }^{\mathrm{a}-\mathrm{j} A l l}$ values are means $\pm \mathrm{SD}$; Values with in the same column with different superscript are significantly $(\mathrm{P}<0.05)$ different

T1 - T16: Treatment 1 - Treatment 16.

From the blended pre ripened provolone cheese, higher ash content $(3.49 \pm 0.07),(3.40 \pm 0.12)$ and $(3.08 \pm 0.04)$ found in samples T10, T9 and T6 respectively. On the other hand, the cheese prepared from cow milk had significantly $(\mathrm{P}<0.0001)$ lower than the other cheese samples. The ash content of cheese was higher when the proportion of camel milk increased. In this study, the ash content of the cheese is higher than the result reported by Oladipo and Jadesim (2013) as they observed lower content. This might be influenced by the strength of the brine solution used during cheese preparation. The average ash content of cheese recorded in the present study for cow milk cheeses were in line with the observations of (Zedan et al., 2014). They found $1.17 \%$ ash content in cow milk cheese. The ash content of the pre ripened provolone cheese samples analyzed in the present study is also higher than the ash content (1.16\%) of Ayib reported by Kassa (2008). This might be the difference in cheese preparation and milk types.

Lactose content of pre ripened provolone cheese samples presented in Table 6. Sample coded T9 has contained the lowest lactose content $(0.75 \pm 0.029)$ than other cheeses. The control has contained remarkably higher lactose content $(2.98 \pm 0.33)$ than other blended provolone cheeses. Fermented dairy products have been reported to be more nutritious than the milk from which they are made (Zhang, 2006). The higher nutritional value of these products has been attributed to the increased production or availability of certain nutrients and to the pre-hydrolysis of the major milk components by lactic starter cultures, rendering them more digestible.

\subsection{Cheese Yield and Component Recovery}

The recovery for different treatments from different blends of milk ranged from 64.87 to $95.39 \%$ for fat, 54.58 to $84.67 \%$ for protein, and 41.35 to $59.92 \%$ for total solid (Table 8 ). Pre ripened provolone cheese prepared from $(60 \%$ cow, $10 \%$ doe and $30 \%$ ewe) milk had significantly $(\mathrm{P}<0.0001)$ higher total solids recovery and fat recovery than the other cheese samples and the lowest component recovery was for T10 (60\% cow, 10\% doe, $10 \%$ ewe and $20 \%$ camel) milk. The additions of camel milk to cow, goat and sheep milk decreased the total recovery of protein. T10 had significantly $(\mathrm{P}<0.0001)$ lower total solids recovery than the other cheese including the control cheese. On the other hand, recovery of protein $(54.58 \%)$ is lower in T10 than other cheese treatment.

Further increase in the camel milk proportion exhibited a downward trend in the TS recovery. Hanna (2015) 
found that the TS recovery was lower in camel milk cheese followed by cow milk cheese and were relatively high in cow milk cheese. When the blending proportion of sheep milk increased with cow, doe and camel milk, the recovery of total solids and fat increased. El-zougby (1988) found similar trend of results being higher recovery of protein and fat for ewe milk cheese. In the current study, the addition of sheep milk reduced the ratio of milk total solids retained in the whey and increases the total solids recovery of cheese. This supported the previous report that the recovery rate of milk solids in the cheese is significantly increased; after enriching camel milk with ewe milk, recovery increased, respectively, instead of only $37 \%$ for the pure camel milk (Ramet, 2001).

The yield of cheese was calculated for fresh cheese and results were tabulated (Table 8). The cheese prepared from T12 (60\% cow, $10 \%$ doe and 30\% ewe) milk had significantly $(\mathrm{P}<0.0001)$ higher yield $(13.47 \%)$ than other cheese samples, while the cheese made fromT10 (60\% cow, $10 \%$ doe, $10 \%$ ewe and $20 \%$ camel) milk gave the lowest yield (9.22\%). The control cheese had cheese yield of $11.13 \%$ and it is significantly differ from T12.

The lower cheese yield in T10 is due to high amount of camel milk from the other treatments. Ramet, (2001) reported that camel milk contains abnormally low milk solids and its cheese processing ability is poor due to differences in availability of $\kappa$-casein and it has more large casein micelles than goat and cow milk. Zhang et al. (2005) reported that the low content in k-casein and its ratio to total proteins in addition to the lack of blactoglobulins are the main factors that limit cheese making performances and cheese yield from camel milk. Mixing the sheep milk with the other milk raised the yield of cheese treatments increased. The highest cheese yield of $30 \%$ sheep milk from the other treatments is due to the higher TS of milk for the cheese preparation and higher recovery of components as compared with the other blends of milk. It is a very important parameter: the higher the recovered percentage of solids, the greater is the amount of cheese obtained and therefore gains in economic terms (Mona et al., 2011). Anifantakis (1990) reported that higher Feta cheese yield was obtained from milk that has higher total solids content. The yield of cheese in this study considerably deviates from the findings of Hühn et al. (1986) who reported 8-10\% for cheese made from cow milk. Marcus (2015) reported that the water-bath cooling after the press made the cheeses, increase in weight due to absorption of water.

Table 5: Component recovery and yield of pre ripened provolone cheese samples

\begin{tabular}{lllll}
\hline \multicolumn{1}{c}{ Treatments } & Fat recovery (\%) & Protein recovery (\%) & TS recovery (\%) & Yield (\%) \\
\hline Control & $71.96 \pm 0.56^{\mathrm{d}-\mathrm{g}}$ & $75.17 \pm 0.68^{\mathrm{b}}$ & $50.27 \pm 0.14^{\mathrm{efg}}$ & $11.13 \pm 0.04^{\mathrm{fg}}$ \\
$\mathrm{T}_{1}$ & $70.99 \pm 0.24^{\mathrm{d}-\mathrm{g}}$ & $74.96 \pm 3.54^{\mathrm{b}}$ & $50.68 \pm 0.08^{\mathrm{def}}$ & $11.25 \pm 0.07^{\mathrm{efg}}$ \\
$\mathrm{T}_{2}$ & $68.91 \pm 2.57^{\mathrm{fgh}}$ & $73.81 \pm 2.45^{\mathrm{b}}$ & $49.79 \pm 0.22^{\mathrm{efg}}$ & $11.08 \pm 0.04^{\mathrm{fg}}$ \\
$\mathrm{T}_{3}$ & $82.10 \pm 0.93^{\mathrm{c}}$ & $73.59 \pm 0.54^{\mathrm{b}}$ & $53.26 \pm 1.07^{\mathrm{c}}$ & $11.98 \pm 0.11^{\mathrm{c}}$ \\
$\mathrm{T}_{4}$ & $69.85 \pm 1.11^{\mathrm{efg}}$ & $73.31 \pm 1.82^{\mathrm{b}}$ & $52.45 \pm 0.53^{\mathrm{cd}}$ & $11.48 \pm 0.18^{\mathrm{de}}$ \\
$\mathrm{T}_{5}$ & $70.50 \pm 0.89^{\mathrm{d}-\mathrm{g}}$ & $67.31 \pm 1.20^{\mathrm{cd}}$ & $51.20 \pm 0.43^{\mathrm{de}}$ & $11.48 \pm 0.17^{\mathrm{de}}$ \\
$\mathrm{T}_{6}$ & $67.70 \pm 2.40^{\mathrm{gh}}$ & $66.54 \pm 2.92^{\mathrm{cd}}$ & $49.02 \pm 0.67^{\mathrm{fg}}$ & $11.28 \pm 0.03^{\mathrm{ef}}$ \\
$\mathrm{T}_{7}$ & $72.75 \pm 2.52^{\mathrm{def}}$ & $63.29 \pm 4.68^{\mathrm{d}}$ & $48.53 \pm 0.09^{\mathrm{g}}$ & $11.23 \pm 0.04^{\mathrm{efg}}$ \\
$\mathrm{T}_{8}$ & $71.28 \pm 4.58^{\mathrm{d}-\mathrm{g}}$ & $71.68 \pm 0.75^{\mathrm{bc}}$ & $46.02 \pm 0.18^{\mathrm{h}}$ & $11.20 \pm 0.07^{\mathrm{efg}}$ \\
$\mathrm{T}_{9}$ & $68.27 \pm 0.62^{\mathrm{fgh}}$ & $57.35 \pm 1.92^{\mathrm{e}}$ & $43.70 \pm 1.0^{\mathrm{i}}$ & $10.05 \pm 0.14^{\mathrm{i}}$ \\
$\mathrm{T}_{10}$ & $64.87 \pm 3.06^{\mathrm{h}}$ & $54.58 \pm 1.43^{\mathrm{e}}$ & $41.35 \pm 2.33^{\mathrm{j}}$ & $9.22 \pm 0.32^{\mathrm{j}}$ \\
$\mathrm{T}_{11}$ & $74.45 \pm 0.53^{\mathrm{c}}$ & $74.38 \pm 0.86^{\mathrm{b}}$ & $50.82 \pm 0.17^{\mathrm{def}}$ & $10.93 \pm 0.18^{\mathrm{gh}}$ \\
$\mathrm{T}_{12}$ & $95.39 \pm 0.99^{\mathrm{a}}$ & $84.67 \pm 0.47^{\mathrm{a}}$ & $59.92 \pm 1.49^{\mathrm{a}}$ & $13.47 \pm 0.11^{\mathrm{a}}$ \\
$\mathrm{T}_{13}$ & $74.31 \pm 1.90^{\mathrm{de}}$ & $73.70 \pm 4.97^{\mathrm{b}}$ & $50.93 \pm 0.27^{\mathrm{def}}$ & $11.62 \pm 0.18^{\mathrm{d}}$ \\
$\mathrm{T}_{14}$ & $82.14 \pm 1.53^{\mathrm{c}}$ & $75.32 \pm 1.75^{\mathrm{b}}$ & $51.04 \pm 0.39^{\mathrm{def}}$ & $11.35 \pm 0.14 \mathrm{~d}^{\mathrm{ef}}$ \\
$\mathrm{T}_{15}$ & $87.38 \pm 1.41^{\mathrm{b}}$ & $83.75 \pm 0.32^{\mathrm{a}}$ & $57.00 \pm 1.12^{\mathrm{b}}$ & $12.70 \pm 0.14^{\mathrm{b}}$ \\
$\mathrm{T}_{16}$ & $71.96 \pm 0.31^{\mathrm{d}-\mathrm{g}}$ & $66.25 \pm 0.47^{\mathrm{dd}}$ & $49.34 \pm 0.95 \mathrm{e}^{\mathrm{fg}}$ & $10.73 \pm 0.04^{\mathrm{d}}$ \\
\hline
\end{tabular}

${ }^{\mathrm{a}-\mathrm{j} A l l}$ values are presented in mean \pm standard deviation; Values within the same column with different superscript letters are significantly $(\mathrm{p}<0.05)$ different from each other.

T1-T16: Treatment 1-Treatment 16

\subsection{Bioactive Compounds of Pre ripened Provolone Cheese}

3.3.1. Ascorbic acid

The ascorbic acid content of pre ripened provolone cheese made from $(60 \%$ cow, $10 \%$ doe, $10 \%$ ewe and $20 \%$ camel) milk $(\mathrm{T} 10)$ scored significantly $(\mathrm{P}<0.0001)$ higher $(3.08 \pm 0.12)$ content than the control and other treatments. The ascorbic acid content of cow milk pre ripened provolone cheese was $0.49 \pm 0.06$. This value is significantly lower than the other cheeses samples. Ascorbic acid decreased with decreasing blend proportion of camel milk. This result indicated that camel milk could be a good source of ascorbic acid. In the current study, pre ripened provolone cheese made from higher proportion of camel milk from other treatments had high ascorbic acid content. This is due to the fact the feed of camel milk is differ from other species and camel consume different herbs and plants, which have high content of ascorbic acid (El-Hatmi et al., 2006). Ascorbic acid plays a major part in the medicinal reputation of camel milk (Konuspayeva et al., 2011). In the current studies, the ascorbic acid 
content of pre ripened provolone cheese was analyzed. However, the other finding did the fresh milk of different milks. In the current study, the ascorbic acid content of cheese is lower than other works that did on fresh milk. This difference might be due to the treatment of heat. Mohamed et al. (2005) reported that ascorbic acid is highly unstable (especially with temperature change).

\subsubsection{Total polyphenols}

Total polyphenols content of pre ripened provolone cheese samples were in the range between $1.00 \pm 0.28$ to $17.50 \pm 0.71$. The cheese prepared from $(60 \%$ cow, $10 \%$ doe, $10 \%$ ewe and $20 \%$ camel) milk scored significantly $(\mathrm{P}<0.0001)$ higher total polyphenol $(17.50 \pm 0.71)$ content than the cheese made from other treatments, while the cheese made from $100 \%$ cow milk (control) had lower amount total polyphenols. It was observed that the bioactive compounds of pre ripened provolone cheese were decreasing with decreasing blend proportion of camel milk.

The difference in total polyphenols of the cheese in the current study could be due to the different milk types and feeding systems. The presence of phenolic compounds in the milk and later in the cheese is a result of their transfer from plant to milk. According to Hilario et al. (2010), pasture plants are rich and significant source of bioactive components and they can transfer into the milk and cheese. In the current study the total polyphenols content of the cheese samples is contradict with the finding of Vesna Levkov (2014). This is due to the processing method during cheese preparation. It was found that salting negatively influenced the total polyphenol concentration by hiding the approach of the phenolic compounds to react with Folin reagent (Hala et al., 2010). In the current finding total polyphenol was observed in all pre ripened provolone cheese samples. This is because the presence of phenolic compounds in the pre ripened provolone cheese might be attributed to the pasture, animal metabolism and amino acid catabolism or microbial activity (Lopez and Lindsay, 1993).

Table 6: Bioactive compounds of pre ripened provolone cheese made from different blends of milk

\begin{tabular}{lll}
\hline Treatments & Ascorbic acid (mg/kg) & $\begin{array}{c}\text { Total Polyphenols } \\
\text { (mg GAE/g ) }\end{array}$ \\
\hline Control & $0.49 \pm 0.06^{\mathrm{i}}$ & $1.00 \pm 0.28^{\mathrm{h}}$ \\
$\mathrm{T}_{1}$ & $1.23 \pm 0.13^{\mathrm{h}}$ & $4.80 \pm 0.28^{\mathrm{g}}$ \\
$\mathrm{T}_{2}$ & $1.50 \pm 0.13^{\mathrm{g}}$ & $5.10 \pm 0.14^{\mathrm{g}}$ \\
$\mathrm{T}_{3}$ & $1.98 \pm 0.07^{\mathrm{f}}$ & $5.67 \pm 0.38^{\mathrm{g}}$ \\
$\mathrm{T}_{4}$ & $2.03 \pm 0.00^{\mathrm{ef}}$ & $5.34 \pm 0.09^{\mathrm{g}}$ \\
$\mathrm{T}_{5}$ & $2.16 \pm 0.06^{\mathrm{ef}}$ & $6.10 \pm 1.56^{\mathrm{g}}$ \\
$\mathrm{T}_{6}$ & $2.24 \pm 0.19^{\text {ed }}$ & $10.50 \pm 0.42^{\mathrm{de}}$ \\
$\mathrm{T}_{7}$ & $2.20 \pm 0.13^{\mathrm{ef}}$ & $9.24 \pm 0.141^{\mathrm{ef}}$ \\
$\mathrm{T}_{8}$ & $2.16 \pm 0.18^{\mathrm{ef}}$ & $8.20 \pm 0.47^{\mathrm{f}}$ \\
$\mathrm{T}_{9}$ & $2.73 \pm 0.13^{\mathrm{b}}$ & $15.30 \pm 1.84^{\mathrm{b}}$ \\
$\mathrm{T}_{10}$ & $3.08 \pm 0.12^{\mathrm{a}}$ & $17.50 \pm 0.71^{\mathrm{a}}$ \\
$\mathrm{T}_{11}$ & $2.47 \pm 0.12^{\mathrm{cd}}$ & $14.07 \pm 0.57^{\mathrm{b}}$ \\
$\mathrm{T}_{12}$ & $2.69 \pm 0.06^{\mathrm{bc}}$ & $12.34 \pm 0.76^{\mathrm{c}}$ \\
$\mathrm{T}_{13}$ & $2.51 \pm 0.06^{\mathrm{bc}}$ & $14.44 \pm 0.15^{\mathrm{b}}$ \\
$\mathrm{T}_{14}$ & $2.03 \pm 0.25^{\mathrm{ef}}$ & $10.54 \pm 0.37^{\mathrm{de}}$ \\
$\mathrm{T}_{15}$ & $1.98 \pm 0.06^{\mathrm{f}}$ & $11.37 \pm 0.24^{\mathrm{cd}}$ \\
$\mathrm{T}_{16}$ & $2.07 \pm 0.05^{\mathrm{ef}}$ & $13.84 \pm 0.62^{\mathrm{b}}$ \\
\hline
\end{tabular}

${ }^{\mathrm{a}-\mathrm{i}}$ All values are presented in mean \pm standard deviation; Values within the same column with different superscript letters are significantly $(\mathrm{p}<0.05)$ different from each other.

T1-T16: Treatment 1-Treatment 16

\subsection{Microbial Quality of Pre ripened Provolone Cheese}

The main microbiological group in the cheese after preparation was TBC. The initial mean (day 1 storage) of TBC counts for the pre ripened provolone cheese samples were in the range between $2.26 \mathrm{log}$ cfu/g for T10 and 3.63 $\log \mathrm{cfu} / \mathrm{g}$ for control (Table 10). This microbial group showed an increase during storage time and reached values in the range of 3.14 to $5.24 \mathrm{log} \mathrm{cfu} / \mathrm{g}$ ( $3^{\text {rd }}$ day storage). The cheese prepared from cow milk had high TBC during storage $\left(1^{\text {st }}\right.$ up to $\left.3^{\text {rd }}\right)$ days. This is due to reduction in $\mathrm{pH}$, which has an inhibitory effect on the growth of some natural micro flora other than total count bacteria (Wakil and Ajayi, 2013). Pre ripened provolone cheese made from T10 (60\% cow, 10\% doe, 10\% ewe and 20\% camel milk) had low TBC from other cheese samples during storage day. This might be due to high proportion of camel milk from the other treatments and there is low production of lactic acid bacteria in this treatment. This result is comparable with the findings of (Mohamed and El-Zubeir, 2012). The total bacteria count of provolone cheese samples observed in this study is lower than the corresponding value reported by (Ashenafi, 1990). This might be associated to its low $\mathrm{pH}$ and low moisture content of cheese samples. On the other hand, the TBC of the current cheeses were higher than that cheddar cheese (Bezaye et al., 2012). This is might be due to the type of milk used for cheese preparation, the flora in raw milk, the processing conditions and contamination after heat treatment affect the microbiological quality of cheese product 
(Varga, 2007)

The means of TCC count for provolone cheeses at $1^{\text {st }}$ day were in the range between 2.39 to $4.42 \log \mathrm{cfu} / \mathrm{g}$. Means of TCC for all treatments of cheese except T9 and T10 cheese were high during the first day and then gradually decreased at day 2 and 3 (Table 10). This might be due to the lack of proper handling and hence contamination by microorganisms during storage (Shuiep et al., 2007). The TCC of cheese samples made from cow milk (control) has the highest coliform count at the first day and decreased to $2.27 \log \mathrm{cfu} / \mathrm{g}$ on the $3^{\text {rd }}$ day. The lower coliform count was observed T9 and T10 throughout the storage day. In the current study the cheese samples prepared from high proportion of camel milk from other treatments had low coliform during storage. In all cheese types that have $10 \%, 15 \%$ and $20 \%$ camel milk the TCC at third day was not detected. This may be because of camel milk was reported to have an antimicrobial effect against Gram positive and Gram negative bacteria, including Escherichia coli, Listeria monocytogenes, Staphylococcus aureus and Salmonella typhimurium (Benkerroum et al., 2004). The TCC obtained in this study was lower than reported by Seifu et al. (2013) and Yigrem and Welearegay (2015) which was $5.7 \mathrm{log} \mathrm{cfu} / \mathrm{ml}$ and $6.14 \mathrm{log} \mathrm{cfu} / \mathrm{ml}$ for Ethiopian unpasteurized traditional fermented products, Ayib. According to international standards, soft cheese should not contain more than $100 \mathrm{cfu} / \mathrm{ml}$ coliforms bacteria (Law, 1999). However in the current study high coliform counts was observed. This might be due to production of milk and cheese under poor conditions. In general the counts of TCC continuously decreased from the first day of storage to the final $\left(3^{\text {rd }}\right.$ day) of storage. The various metabolites excreted by $\mathrm{LAB}$ and the decrease in $\mathrm{pH}$ as a result of their high acidifying capability may partially explain the reduction and disappearance of the total coliform (Cenci-Goga et al., 2008).

The YMC of pre ripened provolone cheese made from different blends of milk was presented (Table 11). The means of YMC for cheeses made using different blends of milk was in the range between 1.72 to $2.75 \mathrm{log} \mathrm{cfu} / \mathrm{g}$ and 2.42 to $3.59 \mathrm{log} \mathrm{cfu} / \mathrm{g}$ at beginning and third day of storage respectively. The maximum number of YMC was found to be $2.75 \mathrm{log} \mathrm{cfu} / \mathrm{g}$ (T13) and minimum $1.72 \mathrm{log} \mathrm{cfu} / \mathrm{g}$ (T8) at first day. This number increased maximum to $3.59 \log \mathrm{cfu} / \mathrm{g}$ (T10) during three days storage period. The highest y YMC was obtained throughout storage time ( $1^{\text {st }}$ up to $3^{\text {rd }}$ day). The acceptable standard count of yeast and mold forming bacteria was $<10,000 \mathrm{sfu} / \mathrm{ml}$ (Norrung 2000). The results of the present study showed that the pre ripened provolone cheese made from pure cow milk and different blends of cow, doe, ewe and camel milk, contained yeast and mold below the standard acceptable level. The YMC of treated cheese were higher than control cheese. Similarly, the yeast and mold count observed in the current study was higher than that reported by Asfawosen Mamo (2017), which is $1.79 \log \mathrm{cfu} / \mathrm{ml}$ for cheese made from pasteurized milk within the same storage time. This indicates that processing and storage area exposes cheese for recontamination and care should be taken to safe guard the consumer. Other reason that might increase the YMC load in a processed milk product could be the presence of spores in the milk. Spores are formed when the microbes undergo unfavorable conditions. Later when the milk is heat treated, the spores flourish and increase the load of the microbes where also late blowing of cheese was observed due to such factor (Walstra et al., 2006). In general the yeasts and mold count found in the final day cheese ranged in the acceptable limit for consumption. Table 7: Microbial load of pre ripened provolone cheese made from different blends of milk during storage at $4^{\circ} \mathrm{C}$ for 3 days

\begin{tabular}{|c|c|c|c|c|c|c|}
\hline \multirow[t]{2}{*}{ Treatments } & \multicolumn{3}{|c|}{ Total Bacteria Count } & \multicolumn{3}{|c|}{ Total coliform count } \\
\hline & $1^{\text {st }}$ day & $2^{\text {nd }}$ day & $3^{\text {rd }}$ day & $1^{\text {st }}$ day & $2^{\text {nd }}$ day & $3^{\text {rd }}$ day \\
\hline Control & $3.63 \pm 0.50^{\mathrm{a}}$ & $4.70 \pm 0.08^{\mathrm{a}}$ & $5.24 \pm 0.09^{\mathrm{a}}$ & $3.42 \pm 0.07^{\mathrm{a}}$ & $2.76 \pm 0.06^{\mathrm{a}}$ & $2.27 \pm 0.07^{\mathrm{bcd}}$ \\
\hline $\mathrm{T} 1$ & $3.26 \pm 0.32^{\mathrm{ab}}$ & $3.70 \pm 0.16^{\mathrm{de}}$ & $4.14 \pm 0.15^{\mathrm{ef}}$ & $3.34 \pm 0.06^{\mathrm{a}}$ & $2.75 \pm 0.18^{\mathrm{a}}$ & $2.62 \pm 0.07^{\mathrm{a}}$ \\
\hline $\mathrm{T} 2$ & $3.19 \pm 0.01^{\mathrm{ab}}$ & $3.98 \pm 0.11^{\mathrm{b}-\mathrm{e}}$ & $4.70 \pm 0.19^{a-e}$ & $3.20 \pm 0.27^{\mathrm{ab}}$ & $2.73 \pm 0.35^{\mathrm{a}}$ & $2.40 \pm 0.30^{\mathrm{abc}}$ \\
\hline $\mathrm{T} 3$ & $3.12 \pm 0.13^{\mathrm{ab}}$ & $4.09 \pm 0.04^{\mathrm{bcd}}$ & $4.78 \pm 0.17^{\mathrm{a}-\mathrm{d}}$ & $3.07 \pm 0.07^{\mathrm{abc}}$ & $2.71 \pm 0.08^{\mathrm{ab}}$ & $2.54 \pm 0.06^{\mathrm{ab}}$ \\
\hline $\mathrm{T} 4$ & $3.28 \pm 0.37^{\mathrm{ab}}$ & $3.96 \pm 0.34^{\mathrm{b}-\mathrm{e}}$ & $4.55 \pm 0.30^{\text {cde }}$ & $2.98 \pm 0.16^{\mathrm{bcd}}$ & $2.55 \pm 0.05^{\mathrm{abc}}$ & $2.03 \pm 0.37^{\mathrm{d}}$ \\
\hline T5 & $3.22 \pm 0.06^{\mathrm{ab}}$ & $3.84 \pm 0.13^{\mathrm{de}}$ & $4.29 \pm 0.27^{\mathrm{def}}$ & $2.88 \pm 0.06^{\mathrm{b}-\mathrm{e}}$ & $2.46 \pm 0.05^{\mathrm{a}-\mathrm{d}}$ & $2.08 \pm 0.06^{\mathrm{cd}}$ \\
\hline T6 & $3.16 \pm 0.30^{\mathrm{ab}}$ & $3.88 \pm 0.14^{\text {cde }}$ & $4.56 \pm 0.16^{\text {cde }}$ & $2.86 \pm 0.09^{\mathrm{b}-\mathrm{e}}$ & $2.37 \pm 0.17^{\mathrm{a}-\mathrm{d}}$ & ND \\
\hline $\mathrm{T} 7$ & $3.07 \pm 0.11^{\mathrm{ab}}$ & $4.08 \pm 0.37^{\mathrm{bcd}}$ & $4.88 \pm 0.49^{\mathrm{a}-\mathrm{d}}$ & $2.88 \pm 0.08^{\mathrm{b}-\mathrm{e}}$ & $2.35 \pm 0.23^{\mathrm{a}-\mathrm{d}}$ & ND \\
\hline $\mathrm{T} 8$ & $3.58 \pm 0.16^{\mathrm{a}}$ & $4.39 \pm 0.28^{\mathrm{ab}}$ & $4.90 \pm 0.37^{\mathrm{abc}}$ & $2.77 \pm 0.20^{\text {cde }}$ & $2.56 \pm 0.08^{\mathrm{abc}}$ & $2.38 \pm 0.11^{\mathrm{abc}}$ \\
\hline T9 & $2.44 \pm 0.08^{\mathrm{cd}}$ & $3.08 \pm 0.02^{\mathrm{f}}$ & $3.42 \pm 0.08^{\mathrm{gh}}$ & $2.56 \pm 0.07^{\mathrm{ef}}$ & $2.18 \pm 0.06^{\mathrm{cd}}$ & ND \\
\hline $\mathrm{T} 10$ & $2.26 \pm 0.32^{\mathrm{d}}$ & $2.70 \pm 0.16^{\mathrm{g}}$ & $3.14 \pm 0.15^{\mathrm{h}}$ & $2.39 \pm 0.11^{\mathrm{f}}$ & $2.03 \pm 0.08^{\mathrm{d}}$ & ND \\
\hline $\mathrm{T} 11$ & $2.88 \pm 0.19^{b c}$ & $4.0 \pm 0.11^{\mathrm{b}-\mathrm{e}}$ & $4.87 \pm 0.33^{\mathrm{a}-\mathrm{d}}$ & $2.83 \pm 0.23^{\mathrm{b}-\mathrm{e}}$ & $2.25 \pm 0.33^{\mathrm{bcd}}$ & ND \\
\hline $\mathrm{T} 12$ & $3.17 \pm 0.16^{\mathrm{ab}}$ & $4.29 \pm 0.02^{\mathrm{bc}}$ & $5.15 \pm 0.20^{\mathrm{ab}}$ & $2.93 \pm 0.16^{\mathrm{b}-\mathrm{e}}$ & $2.64 \pm 0.13^{\mathrm{abc}}$ & $2.13 \pm 0.16^{\mathrm{cd}}$ \\
\hline $\mathrm{T} 13$ & $2.90 \pm 0.30^{b c}$ & $3.88 \pm 0.03^{\mathrm{de}}$ & $5.12 \pm 0.06^{\text {cde }}$ & $2.66 \pm 0.16^{\mathrm{def}}$ & $2.34 \pm 0.13^{\mathrm{a}-\mathrm{d}}$ & ND \\
\hline $\mathrm{T} 14$ & $3.19 \pm 0.28^{\mathrm{ab}}$ & $4.03 \pm 0.07^{\mathrm{b}-\mathrm{e}}$ & $4.65 \pm 0.02^{\mathrm{b}-\mathrm{e}}$ & $2.91 \pm 0.28^{b-\mathrm{e}}$ & $2.53 \pm 0.34^{\mathrm{abc}}$ & $2.11 \pm 0.28^{\mathrm{cd}}$ \\
\hline $\mathrm{T} 15$ & $3.30 \pm 0.09^{\mathrm{ab}}$ & $3.61 \pm 0.05^{\mathrm{e}}$ & $3.89 \pm 0.04^{\mathrm{fg}}$ & $2.91 \pm 0.09^{\mathrm{b}-\mathrm{e}}$ & $2.57 \pm 0.11^{\mathrm{abc}}$ & $2.01 \pm 0.09^{\mathrm{d}}$ \\
\hline $\mathrm{T} 16$ & $2.82 \pm 0.08^{b c}$ & $3.73 \pm 0.18^{\mathrm{de}}$ & $4.36 \pm 0.31 \mathrm{~d}^{\mathrm{c}-\mathrm{f}}$ & $2.91 \pm 0.16^{\mathrm{b}-\mathrm{e}}$ & $2.32 \pm 0.13^{\mathrm{a}-\mathrm{d}}$ & ND \\
\hline
\end{tabular}

${ }^{a-h}$ All values are presented in mean \pm standard deviation; Values within the same column with different superscript letters are significantly $(p<0.05)$ different from each other. T1-T16: Treatment 1-Treatment 16 
Table 8: Yeast and mold count of pre ripened provolone cheese made from different blends of milk during storage at $4^{\circ} \mathrm{C}$ for 3 days.

\begin{tabular}{|c|c|c|c|}
\hline \multirow[t]{2}{*}{ Treatments } & \multicolumn{3}{|c|}{ YMC Log10cfu/g } \\
\hline & $1^{\text {st }}$ day & $2^{\text {nd }}$ day & $3^{\text {rd }}$ day \\
\hline Control & $2.27 \pm 0.07^{\mathrm{bcd}}$ & $2.66 \pm 0.16 b^{c d}$ & $2.97 \pm 0.07^{\mathrm{b}-\mathrm{e}}$ \\
\hline $\mathrm{T}_{1}$ & $2.62 \pm 0.07^{\mathrm{ab}}$ & $2.85 \pm 0.04^{\mathrm{bc}}$ & $3.32 \pm 0.07^{\mathrm{abc}}$ \\
\hline $\mathrm{T}_{2}$ & $2.40 \pm 0.30^{\mathrm{a}-\mathrm{d}}$ & $2.73 \pm 0.35^{\mathrm{bc}}$ & $3.10 \pm 0.30^{\mathrm{a}-\mathrm{e}}$ \\
\hline $\mathrm{T}_{3}$ & $2.54 \pm 0.06^{\mathrm{abc}}$ & $2.76 \pm 0.06^{\mathrm{bc}}$ & $3.24 \pm 0.06^{\mathrm{a}-\mathrm{d}}$ \\
\hline $\mathrm{T}_{4}$ & $2.03 \pm 0.37^{\mathrm{de}}$ & $2.34 \pm 0.34^{\mathrm{cd}}$ & $2.73 \pm 0.37^{\mathrm{ef}}$ \\
\hline $\mathrm{T}_{5}$ & $2.08 \pm 0.06^{\text {cde }}$ & $2.41 \pm 0.18^{\mathrm{bcd}}$ & $2.78 \pm 0.06^{\mathrm{def}}$ \\
\hline $\mathrm{T}_{6}$ & $2.14 \pm 0.30^{\text {cde }}$ & $2.47 \pm 0.17^{\mathrm{bcd}}$ & $2.84 \pm 0.30^{\mathrm{c}-\mathrm{e}}$ \\
\hline $\mathrm{T}_{7}$ & $2.24 \pm 0.11^{\mathrm{bcd}}$ & $2.55 \pm 0.23^{\mathrm{bcd}}$ & $2.94 \pm 0.11^{\text {cde }}$ \\
\hline $\mathrm{T}_{8}$ & $1.72 \pm 0.16^{\mathrm{e}}$ & $2.06 \pm 0.06^{\mathrm{d}}$ & $2.42 \pm 0.16^{\mathrm{f}}$ \\
\hline $\mathrm{T}_{9}$ & $2.12 \pm 0.01^{\mathrm{cde}}$ & $2.48 \pm 0.06^{\mathrm{bcd}}$ & $2.82 \pm 0.01^{\mathrm{def}}$ \\
\hline $\mathrm{T}_{10}$ & $2.74 \pm 0.18^{\mathrm{a}}$ & $3.48 \pm 0.78^{\mathrm{a}}$ & $3.59 \pm 0.39^{\mathrm{a}}$ \\
\hline $\mathrm{T}_{11}$ & $2.43 \pm 0.19^{\mathrm{a}-\mathrm{d}}$ & $2.70 \pm 0.25^{\mathrm{bcd}}$ & $3.13 \pm 0.19^{\mathrm{a}-\mathrm{e}}$ \\
\hline $\mathrm{T}_{12}$ & $2.13 \pm 0.16^{\text {cde }}$ & $2.49 \pm 0.08^{\mathrm{bcd}}$ & $2.83 \pm 0.16^{\mathrm{c}-\mathrm{e}}$ \\
\hline $\mathrm{T}_{13}$ & $2.75 \pm 0.18^{\mathrm{a}}$ & $3.07 \pm 0.16^{\mathrm{ab}}$ & $3.45 \pm 0.18^{\mathrm{ab}}$ \\
\hline $\mathrm{T}_{14}$ & $2.11 \pm 0.28^{\text {cde }}$ & $2.53 \pm 0.34^{\mathrm{bcd}}$ & $2.81 \pm 0.28^{\mathrm{def}}$ \\
\hline $\mathrm{T}_{15}$ & $2.01 \pm 0.09^{\mathrm{de}}$ & $2.37 \pm 0.03^{\mathrm{cd}}$ & $2.71 \pm 0.09^{\mathrm{ef}}$ \\
\hline $\mathrm{T}_{16}$ & $2.43 \pm 0.16^{\mathrm{a}-\mathrm{d}}$ & $2.77 \pm 0.06^{\mathrm{bc}}$ & $3.13 \pm 0.16^{\mathrm{a}-\mathrm{e}}$ \\
\hline
\end{tabular}

${ }^{\mathrm{a}-\mathrm{f}}$ All values are presented in mean \pm standard deviation; Values within the same column with different superscript letters are significantly $(\mathrm{p}<0.05)$ different from each other.

T1-T16: Treatment 1-Treatment 16

\subsection{Consumer Acceptability of Pre ripened Provolone cheese}

Blending proportion of milk has significant $(\mathrm{P}<0.0001)$ effect on the color of prepared pre ripened provolone cheese. The color score of the different cheese samples ranged from $1.3 \pm 1.66$ to $4.3 \pm 0.99$. Pre ripened Provolone cheese prepared from cow milk has higher mean color value than the other cheese samples. The color of the cow milk cheese in the current study closely related to the results reported by (Pinto et al., 2014). They observed that cow milk cheese is more acceptable in color as compared to the different sources of milk cheese. Sample coded T10 containing (20\% camel milk) has scored the least among other cheeses in color. This might be due to deficiency of shine, which fat provides when present in minute amount. Chawla et al. (1985) observed that low amount of fat results deficiency of shine and lower the quality of color.

The mean value for taste of pre ripened provolone cheese samples were in the range of $1.8 \pm 1.10$ to $4.27 \pm 0.78$. Statistical analysis indicated that different blends of milk have significant $(\mathrm{P}<0.05)$ affect the taste of provolone cheese samples. In this study control (cow milk) cheese was preferable than other treatments and this result in agreements with the findings of Adedokun et al. (2013), as they found variation in taste score of cow milk cheese by using different coagulants. In the contrary Bille et al. (2001) reported that the Gouda cheese prepared from cow milk was less preferable by taste. This is due to the processing and method of cheese preparation. T9 and T10 samples had lower scores for taste than other samples. This might be due to component especially, fat found in the cheese. Pinto et al. (2014) reported that fats play a vital role in defining the representative flavor and taste of cheese. The flavor value of the cheese samples had ranged from $2.20 \pm 0.96$ to $4.23 \pm 0.68$. T1 and control samples had higher scores for flavor than other samples. This could be due to the more amount of lactose available which could contribute to its flavor. T10 (60\% cow, 10\% doe, 10\% ewe and 20\% camel) milk had lower scores for flavor. This might be due to the moisture content of the cheese.

The saltiness value of cow milk cheese was lower compared to the blended milk cheese samples. This might be due to the type of feed available for animals. Sample coded with T10 had the higher value of saltiness. This is due to the high amount of camel milk from other treatments. The taste of camel milk is usually different from other animal species because camels are fed shrubs and herbs in the arid regions due to this the milk has salty taste (El Agamy, 1983). In the current study, the saltiness content of cheese samples was in agreement with the finding of Mitku (2015), who reported saltiness of 2.1 to 3.6. On the other hand, Kanwal et al. (2004) scored low value of saltiness compared to this study. This might be due to the amount of salt added in the cheese during brining.

Texture of cheese prepared from T12 (60\% cow, 10\% doe and 30\% ewe) milk was extremely liked by the panel of judges as compared to rest of the cheese samples. Cheese made from T3 $(70 \%$ cow, $10 \%$ doe and $20 \%$ ewe) milk rank the second highest score and there were no significant differences from T12. This could be attributed to the higher fat content in the milk, which in turn resulted in the smoothness and best texture of the cheese. Pinto et al. (2014) reported that the level of fat content of cheese could enhance the smoothness and texture of cheese. Similarly Bylund, (1995) reported that texture, flavor, mouth feel and consistency are predominantly 
influenced by the fat content of cheese. T10 has lower value by texture from the other treatments; this may be due to the high content of $\mathrm{pH}$ and low moisture content cheese give less texture. Asfawosen (2017) reported that high $\mathrm{pH}$ cheeses are softer than more acid cheeses. In this study, the texture of cheese prepared from different blends of milk was in agreement with (Bezaye et al., 2012).

The average mean values of pre ripened provolone cheese samples varied from 2.39 to 3.42 . The control cheese sample had the highest appearance value from the other cheese samples. However, cheese made from $(60 \%$ cow, $10 \%$ doe, $10 \%$ ewe and $20 \%$ camel) milk was significantly $(\mathrm{P}<0.0001)$ lower appearance value than other cheese samples. In this study, appearance scores were not in agreement with the findings of Drake et al. (2009). This difference might be due to source of milk and its composition.

Statistical analysis specified that the overall acceptability of various cheese samples prepared from different blends of milk showed significance $(\mathrm{P}<0.0001)$ effect by the blending proportion. The control cheese sample containing $100 \%$ cow milk had scored the highest overall acceptability (4.67) by panelists among the other cheese samples. This study was in agreement with hanna, (2015) who developed soft cheese from cow milk scored the highest in overall acceptability. Pre ripened provolone cheese prepared from $(60 \%$ cow, $10 \%$ doe, $10 \%$ ewe and $20 \%$ camel) milk (T10) sample had lower score for overall acceptability. Overall acceptability of provolone cheese appeared to be slightly higher than that reported by Pinto et al. (2014), who found a mean score of 2.23 to 2.99. On the other hand, overall acceptability scores were not in agreement with the findings of Drake et al. (2009), as they observed significantly lower score. Hence, concluded that source of milk and its composition have significantly influenced the overall acceptability of the current provolone cheese.

Table 9: Sensory characteristics of pre ripened provolone cheese made from different blends of whole milk

\begin{tabular}{|c|c|c|c|c|c|c|c|}
\hline Treatments & Color & Taste & Flavor & Saltiness & Texture & Appearance & Overall acceptability \\
\hline Control & $4.3 \pm 0.99^{\mathrm{a}}$ & $4.27 \pm 0.78^{\mathrm{a}}$ & $4.23 \pm 0.68^{\mathrm{a}}$ & $1.9 \pm 1.12^{\mathrm{g}}$ & $3.9 \pm 0.71^{\mathrm{abc}}$ & $4.33 \pm 0.80^{\mathrm{a}}$ & $4.67 \pm 0.55^{\mathrm{a}}$ \\
\hline $\mathrm{T} 1$ & $4.23 \pm 0.86^{\mathrm{a}}$ & $4.07 \pm 0.64^{\mathrm{ab}}$ & $4.03 \pm 0.85^{\mathrm{ab}}$ & $2.4 \pm 1.00^{\mathrm{fg}}$ & $3.3 \pm 1.15^{\mathrm{cd}}$ & $4.14 \pm 0.78^{\mathrm{a}}$ & $4.4 \pm 0.72^{\mathrm{ab}}$ \\
\hline $\mathrm{T} 2$ & $3.8 \pm 1.1^{\mathrm{ab}}$ & $3.97 \pm 1.00^{\mathrm{ab}}$ & $3.9 \pm 0.96^{\mathrm{abc}}$ & $2.53 \pm 0.68^{\mathrm{ed}}$ & $3.37 \pm 1.07^{\mathrm{bcd}}$ & $4.16 \pm 0.79^{\mathrm{a}}$ & $4.14 \pm 0.94^{b}$ \\
\hline $\mathrm{T} 4$ & $3.8 \pm 0.76^{\mathrm{ab}}$ & $3.67 \pm 0.8^{\mathrm{bc}}$ & $3.57 \pm 0.86 \mathrm{a}^{\mathrm{bcd}}$ & $2.97 \pm 1.38^{\mathrm{ef}}$ & $3.37 \pm 1.06^{\mathrm{bcd}}$ & $4.03 \pm 0.80^{\mathrm{a}}$ & $4.26 \pm 0.69^{\mathrm{ab}}$ \\
\hline T5 & $3.37 \pm 1.27^{\mathrm{bc}}$ & $3.6 \pm 0.67^{\mathrm{bc}}$ & $3.5 \pm 0.82^{\mathrm{cd}}$ & $2.43 \pm 1.10^{\mathrm{f}}$ & $3.03 \pm 0.93^{\mathrm{d}}$ & $3.37 \pm 1.22^{\mathrm{b}}$ & $3.13 \pm 0.77^{\mathrm{d}-\mathrm{g}}$ \\
\hline T6 & $2.97 \pm 1.10^{\mathrm{cd}}$ & $3.03 \pm 1.10^{\mathrm{de}}$ & $3.37 \pm 0.93^{\mathrm{d}}$ & $2.47 \pm 1.20^{\mathrm{ef}}$ & $2.7 \pm 1.47^{\mathrm{de}}$ & $2.93 \pm 1.11^{\mathrm{bcd}}$ & $3.4 \pm 0.93^{\text {cde }}$ \\
\hline T9 & $2.9 \pm 1.21^{\mathrm{de}}$ & $2.37 \pm 1.03^{\mathrm{f}}$ & $2.3 \pm 0.99^{\mathrm{fg}}$ & $4.03 \pm 1.19^{\mathrm{ab}}$ & $2.27 \pm 1.01^{\mathrm{ef}}$ & $2.44 \pm 1.10^{\mathrm{fd}}$ & $2.33 \pm 0.99^{\mathrm{h}}$ \\
\hline $\mathrm{T} 10$ & $1.83 \pm 1.02^{\mathrm{g}}$ & $1.8 \pm 1.10^{\mathrm{g}}$ & $2.2 \pm 0.96^{\mathrm{g}}$ & $4.2 \pm 1.00^{\mathrm{a}}$ & $2.1 \pm 1.54^{\mathrm{f}}$ & $1.93 \pm 1.17^{\mathrm{e}}$ & $1.63 \pm 0.81^{\mathrm{i}}$ \\
\hline $\mathrm{T} 11$ & $2.5 \pm 0.97^{\mathrm{def}}$ & $2.93 \pm 1.11^{\mathrm{def}}$ & $3.1 \pm 0.88^{\mathrm{de}}$ & $3.53 \pm 0.90^{\mathrm{b}-\mathrm{e}}$ & $2.77 \pm 1.52^{\mathrm{de}}$ & $2.96 \pm 1.03^{\mathrm{bcd}}$ & $3.7 \pm 0.60^{c}$ \\
\hline $\mathrm{T} 12$ & $2.5 \pm 1.17^{\mathrm{def}}$ & $2.97 \pm 1.13^{\mathrm{de}}$ & $2.87 \pm 0.90^{\mathrm{e}}$ & $3.13 \pm 1.07^{\mathrm{de}}$ & $4.5 \pm 0.63^{\mathrm{a}}$ & $3.34 \pm 0.80^{\mathrm{b}}$ & $3.3 \pm 0.65^{\mathrm{d}-\mathrm{g}}$ \\
\hline $\mathrm{T} 13$ & $2.23 \pm 0.97^{\mathrm{efg}}$ & $2.9 \pm 0.71^{\mathrm{cde}}$ & $2.7 \pm 0.95^{\mathrm{ef}}$ & $3.27 \pm 0.91^{\mathrm{cde}}$ & $2.93 \pm 1.20^{\mathrm{d}}$ & $2.8 \pm 0.85^{\mathrm{bcd}}$ & $3.56 \pm 0.97^{\mathrm{cd}}$ \\
\hline
\end{tabular}

${ }^{\mathrm{a}-\mathrm{i}}$ All Values are mean \pm standard deviation; values with the same column with different superscript are significantly $(\mathrm{p}<0.05)$ different.

T1-T2: Treatment 1-Treatment 16

\section{CONCLUSION}

In this study, proximate analysis result pre ripened provolone cheese, which was prepared from $(60 \%$ cow, $10 \%$ doe and 30\% ewe) milk (T12) was best quality in terms of Protein, total solid, fat content and moisture content. Cheese Sample contained 20\% camel milk (T10) was best based on ash content. The finding of this study also showed that pure cow milk was best by lactose content from the other cheese samples. The mineral content and bioactive contents (vitamin $\mathrm{c}$ and total polyphenols) of pre ripened provolone cheeses were significantly affected $(\mathrm{P}<0.0001)$ by blending proportions. In this finding the pre ripened provolone cheese, prepared from $(60 \%$ cow, $10 \%$ doe, $10 \%$ ewe and $20 \%$ camel) milk (T10) had better mineral content. Beside this, it was best by vitamin c and total polyphenols content from the other cheese samples. In this finding, cheese samples which have high proportion of camel milk from the other treatments was best hygienic quality in terms of total coliforms. This finding showed that the color, taste flavor, appearance and overall acceptability of control (100\% cow) milk cheese were better liked. Finally, it can be concluded that the development of pre ripened provolone cheese making technology from blends of cow, doe, ewe and camel milk is functional not only for the investors but also for the development of the country.

\section{REFERENCES}

Abdel E., Dirar H.A. and Osman M. 2009. Microbiological and biochemical changes and sensory evaluation of camel milk fermented with selected bacterial starter cultures. African Journal of Food Science. 3(12):398405.

Abdel E.S., Rasha A., Mohamed Ali, Kamal A. and Abdel Razig. 2012. Production and Effect of Storage in the 
Chemical Composition of Mozzarella Cheese. International Journal of Food Science and Nutrition Engineering. 2(3): 21-26.

Adedokun I.I., Okorie S.U., Onyeneke E.N. and Anoruo S.A. 2013. Evaluation of yield, sensory and chemical characteristics of soft unripened cheese produced with partial incorporation of bambaranut milk. Academic Journal of Food Research 1 (1), 14-18.

Adegoke G.o., Nse E. N. \& Alkanni, A. O. (1992). Effects of heat, processing time and pH on the micro flora, aflatoxin content and storability of wara, a soft cheese. Die Nahrung, 36(3), 259-264.

Ahmed NA. and El Zubeir I. 2011. Effect of salt level on some physical and chemical properties and acceptability of camel milk cheese. Journal of Camel Science. 4: 40-48.

Amenu and deeth. 2007. The impact of milk composition on cheddar cheese manufacture. The Australian Journal of Dairy Technology. Vol. 62 , no. 3

Anifantakis E. 1986. Comparison of the physico-chemical properties of ewe's and cow's milk. In: International Dairy Federation (Ed.), Proceedings of the IDF Seminar Production and Utilization of Ewe's and Goat's Milk, Athens, Greece . 202. pp. 42-53.

AOAC, Official Methods of Analysis. 2006. Association of Official Analytical chemists19 ${ }^{\text {th }}$ Edition USA: Washington D. C.

Asfawosen Mamo. 2017. Cheddar Cheese Characterization and Its Biochemical Change during Ripening. International Journal of Advanced Scientific Research and Management, Vol. 2 Issue 5.

Ashenafi M. 2006. A review on the microbiology of indigenous fermented foods and beverages of Ethiopia. Ethiopia Journal of Biology science. 5(2):189-245.

Azarnia S., Robert N. and Lee B. 2006. Biotechnological methods to accelerate Cheddar cheese ripening. Critical Reviews in Biotechnology, 26, 121-143.

Bezaye Taye, Shimelis Admassu and Yogesh K. 2012. Bio-Chemical and Textural Changes in Pre-Ripening Stages During Manufacture of Cheddar Cheese from Different Blends of Doe and Ewe Milk. World Journal of Dairy \& Food Sciences 7 (1): pp49-53.

Bille P.G., Hiwelepo P. and E. L. Keya. 2001. Examining the need for the use of calcium chloridein the processing of Gouda cheese made from pasteurized milk. The Journal of Food Technology in Africa, Vol. 6, No. 2, Apr-June, 2001, 44-47.

Bylund G. 1995. Dairy processing Handbook. Lund, Sweden. Tetra packs processing systems. pp 18-19.

Cenci-Goga B.T., Ranucci, D., Miraglia, D. and Ciuffi, A. 2008. Use of starter cultures of dairy origin in the production of Salame nostrano, an Italian dry-cured sausage. Meat Science 78: 381-390.

Chawla A. K., Singh S. \& Kanawjia S. K. 1985 Development of low fat paneer. Indian Journal of Dairy Science 38: $280-283$.

Claudia Anesini, Graciela E. Ferraro, and Rosana Filip . (2008). Total Polyphenol Content and Antioxidant Capacity of Commercially Available Tea (Camellia sinensis) in Argentin. J. Agric. Food Chem, 56, 92259229.

Codex Standard. 2007. Codex standard for provolone cheese. Formerly Codex Stan C-15-2016.

Derar A. and El Zubeir IEM. 2014. Compositional Content of White Cheese Manufactured from Mixtures of Camel and Sheep Milk during Storage. Journal of Food Nutrition Disorder 3:3.

Drake S. L., Lopetcharat K. \& Drake M. A. 2009. Comparison of two methods to explore consumer preferences for cottage cheese. Journal of Dairy Science. 92: 5883-5897

El - Agamy E. I., Nawar M. A., Shamsia S. and Awad S. 2006. The convenience of camel milk proteins for the nutrition of cow milk allergic children. The 4th Saudi Conference on Food and Nutrition, $10-12$ December, Riyadh, Saudi Arabia.

El-Agamy E. I. 2000. Effect of heat treatment on camel milk proteins with respect to antimicrobial factors: A comparison with cows' and buffalo milk proteins. Journal of Food Chem. 68: 227-232.

El-Hatmi H., Khorchani T. and Attia H. 2006.Characterization and composition of camel's (Camelus dromedarius) colostrum and milk, Microbiol. Hyg. Alim. 18, 13-17.

Enb A., Abou Donia N.S,. Abd-Rabou A., Abou-Arab and El-Senaity M.H. 2009.Chemical compostion of raw milk and heavy metals behavior during processing of milk products. Global Vet., 3:268-275.

Fasakin A. and C. Unokiwedi, 1992. Chemical analysis of fermented cheese obtained from Cow milk and melon. Nigerian Journal of Microbiology., 5: 559-566.

Felleke G. 2003. A Review of the Small Scale Dairy Sector - Ethiopia. FAO Prevention of Food Losses Program: Milk and Dairy Products, Post-harvest Losses and Food Safety in Sub Saharan Africa and the Near East.

Frazier WC, Westhoff DC (1998). Food Microbiology. 4th ed. Tata McGraw Hill Publishing Ltd., New Delhi, pp. 276-297

Haider Khan, Izhar Hussain Athar and Muhammad Aslam. 2004. Evaluation of Cheese Prepared by Processing Camel Milk. Pakistan J. Zool., vol. 36(4), pp. 323-326.

Hala M. F., Ebtisam I. G., Sanaa M. B., Gad A. S. and Marwa M. E. 2010. Manufacture of low fat UF-soft cheese 
supplemented with rosemary extract (as natural antioxidant). Journal of American Science, 6 (10), 570-579.

Hanna Asfaw. 2015. Camel milk utilization, marketing system and milk and milk product quality assessment: The case of Boset district. MSc. Thesis, College of Agriculture, Haramaya University, Haramaya. p.96.

Hilario M. C., Puga C. D., Ocaña A. N. and Gil Romo F. P. 2010. Antioxidant activity, bioactive polyphenols in Mexican goats' milk cheeses in summer grazing. Journal of Dairy Research, 77, 20-26.

Hühn S., Lourenço J. B., Carvalho L. O. M., Nascimento, C.B. \& Vieir, L. C. 1986. Aproveitamento do leite de búfala em produtos derivados. In Anais do $1^{\circ}$ Simpósio do Trópico Úmido (pp. 265-269), Belém, PA. Belém: EMBRAPA/CPATU.

IDF (International dairy federation). 1985. Milk and milk products: methods of sampling (IDF standard $50 \mathrm{~b}$ ).

Iwe M. O. 2010. Some Sensory Methods and Data Analysis. In Handbook of Sensory Methods and Analysis. (Second Eds.). ISBN: 978-32124-8-6, Published In Rojoint Communication Services Ltd, Enugu, Nigeria, Pp. $80-85$.

Kanwal R., Ahmed T. \& Mirza B. 2004. Comparative analysis of quality of milk collected from buffalo, cow, goat and sheep of Rawalpindi/Islamabad region in Pakistan. Asian Plant Science 3: 300-305.

Kassa B. 2008. Cottage cheese production in Shashemene and the role of rue (Ruta chalepensis) and garlic (Allium sativum) on its quality and shelf life. MSc. thesis, Hawassa University, Hawassa, Ethiopia.

Khan, R.S. \& T. Masud. 2013. Comparison of buffalo cottage cheese made from aqueous extract of Withania coagulans with commercial calf rennet. International Journal of Dairy Technology 396-401.

Kheadr E.E., Vuillemard J.C. and El-Deeb S.A. 2003. Impact of liposome-encapsulated enzyme cocktails on cheddar cheese ripening. Food Res. Int. 36: pp. 241-252.

Konuspayeva G., Faye B. and G. Loiseau. 2011. Variability of vitamin C content in camel milk from Kazakhstan. Journal of Camelid Science. 4 (2011) 63-69.

Lopez V. \& Lindsay R. 1993. Metabolic conjugates as precursors for character- izing flavor compounds in ruminant milks. Journal of Agriculture Food Chemistry. 41: 446-454.

Mahmood, A. and S. Usman, 2010. Comparative Study on the Physicochemical Parameters of Milk Samples Collected from Buffalo, Cow, Goat and Sheep of Gujrat, Pakistan, Pakistan Journal of Nutrition, 9(12): 11921197.

Masud T., Athar I.H. \& Shah M.A. 1992. Comparative Study on Paneer Making from Buffalo and Cow Milk. Dairy Technology Lab, Animal Science Institute, p. 563-556.

Mehaia A. 1993. Fresh soft white cheese (domiati type) from camel's milk: composition, yield, and sensory evaluation. Journal of Dairy Science, 76: 2845-2855.

Ministero Agricoltura e Foreste. 1992. Provolone in DOC Cheeses of Italy Milano, Italy: Ed. Unalat. pp. 89-91.

Mitiku. 2015. Process optimization of milk coagulant extraction from latex of Carica papaya for production of pre ripened cheese. MSc. Thesis, institute of technology, Haramaya University, Haramaya.

Mohamed H.E., Mousa H.M., Beynen A.C.,2005. Ascorbic acid concentrations in milk from Sudanese camels, J. Anim. Physiol.and Anim. Nut. 89, 35-37.

Mona A.M., Abd El-Gawad and Ahmed S. 2011. Cheese Yield as Affected by some Parameters Review. Pol., Technol. Aliment. 10(2) 2011, 131-153.

Nweze CC, Abdulganiyu MG. and Erhabor OG. 2015. Comparativeanalysis of vitamin C in fresh fruits juice of Malusdomestica, Citrussinensi, Ananascomosus and Citrulluslanatus by Iodometric titration.Int. J. Sci. Env. Tech. 4(1): 17-22.

O’Connor C B. 1993.Traditional cheese making manual.ILCA (International Livestock Centre for Africa), Addis Ababa, Ethiopia.

O’Mahoney F .1988. Rural dairy technology Experiences in Ethiopia ILCA manual No 4. Dairy Technology unit. ILCA, Addis Ababa, Ethiopia.p64.

Ogunlade Ayodele Oluwayemisi1, Oyetayo Victor Olusegun, Ojokoh Anthony Okhonlaye. 2017. Percentage Yield and Proximate Composition of Cheese Produced from Sheep Milk Using Different Coagulants. International Journal of Microbiology and Biotechnology; 2(4): 171-175.

Oladipo I.C. and Jadesimi P. D. 2013. Microbiological Analysis and Nutritional Evaluation of West African soft cheese (wara) produced with different preservatives. America Journal of food Nutrition, Vol 3 (1) pp:13-21.

Pandya A.J. \& Ghodke K.M. 2007. Goat and sheep milk products other than cheeses and yoghurt. Small Ruminant Research 68: 193-206.

Pinto S., Bhatt J.D. \& Prajapati J.P. 2014. Evaluation of selected emulsifiers and buttermilk in the manufacture of reduced-fat paneer. Basic Research Journal of Food Science and Technology 1(4): 1-14

Ramet J P. 2001. The technology of making cheese from camel milk (Camelus dromedarius). In FAO Animal Production and Health. No. 113, pp. 74. Rome, Italy: Food and Agriculture Organization of the United Nations.

Richardson G. H. 1985. Standard Methods for the Examination of Dairy Products.15th ed. American Public Health Association.Washington, D.C. pp. 48- 94 
Sadia R., Ihsan M, Ishfaq A, Yasser D., and Zarmeena A, 2016. Comparative Study of Cottage Cheese Prepared from Various Sources of Milk. University of Agriculture, Peshawar, Pakistan Life and Environmental Sciences 53 (4): 269-282.

Shuiep E.S., El Zubeir I.M. and El Owni H.H. 2007. Musa, Assessment of hygienic quality of camel (Camelus dromedarius) milk in Khartoum state, Sudan.Bull. Anim. Health. Prod. Afr., 55, 112-117.

Sintayehu Yigrem and Haile Welearegay. 2015. Assessment of Microbial Quality and Safety of a Traditional Fermented Milk-'Irgo', Collected from Hawassa City, South Ethiopia. College of Agriculture, Hawassa University, Hawassa, Ethiopia. J Food Process Technol 2015, 6:3.

Uaboi - Egbmni P. O, Okolie T. L., Akintunde, O., Bisi Johnson L., Enwe N. and P. O. Bessong. (2010). Pakistian Journal of nutrition 9 (9): 920-25, ISSN 1680- 5194@Asian network for scientific information. U.S Department of Agriculture (USDA) USDA: APHIS: US: CEAH, 2005. NRRC Building B, M. S 2E7 2150 Centre Avenue fort Collins, Co 80526-8117 970.494.7000.

Varga, L. 2007. Microbiological quality of commercial dairy products. Communicating Current Research and Educational Topics and Trends in Applied Microbiology A. Méndez-Vilas (Ed.). pp.487-494.

Vesna Levkov1, Sonja Gadžovska, Oliver Tuševski, Natasha Gjorgovska1 and Nataša Mateva. 2014. Preliminary Study of Total Phenolic Contentin Traditional Sheep Cheese (Bieno Sirenje). Macedonian Journal of Animal Science, Vol. 4, No. 1, pp. 31-35

Walstra Pieter, Wouters T. M. and Tom J. Geurts. 2006. Dairy Science and Technology. Boca Raton: Taylor \& Francis Group, CRC Press.

Zedan I.A., Abou-Shaloue Z. and Zaky S.M. 2014. Quality Evaluation of Mozzarella Cheese from Different Milk Types. Faculty of Agricultural, Alexandria University, Egypt. Alexandria Science Exchange Journal, Vol.35, No.3.

Zelalem Y. and Faye B. 2006. Handling and microbial load of cow's milk and irgo- fermented milk collected from different shops and producers in central highlands of Ethiopia. Ethiopia Journal of Animal Production 6(2)2006:6782.

Zhang H., Yao J., Zhao D., Liu H., and Guo M. 2005. Changes in chemical composition of Alxa bactrian camel milk during lactation. Journal of Dairy Science 88 3402- 3410. 